\title{
Advances in Methane Conversion Processes
}

\author{
Bingwen Wang ${ }^{1}$, Sandra Albarracín-Suazo ${ }^{2}$, Yomaira Pagán-Torres $^{2} *$ and Eranda Nikolla ${ }^{1} *$ \\ ${ }^{I}$ Department of Chemical Engineering and Materials Science, Wayne State University, Detroit, MI, 48202, USA \\ ${ }^{2}$ Department of Chemical Engineering, University of Puerto Rico-Mayagüez Campus, Mayagüez, PR, 00681, USA
}

* Corresponding Authors:

E-mails: erandan@wayne.edu

yomairaj.pagan@upr.edu

(C) 2017. This manuscript version is made available under the Elsevier user license http://www.elsevier.com/open-access/userlicense/1.0/ 


\begin{abstract}
In this short review, we highlight the recent advances in methane conversion processes at high and low temperatures. Methane conversion processes are of great importance in achieving a crude-oil independent supply of energy, fuels and chemicals for the future. Direct conversion of methane into chemicals and fuels has been often considered as the "holy grail" of current catalysis research due to the unreactive nature of methane, which makes targeted chemical transformations to fuels and chemicals very challenging. We discuss the progress in developing heterogeneous catalytic and electrocatalytic systems to overcome this challenge. We conclude by providing a perspective on the future of this area of research.
\end{abstract}

Keywords: Methane; Heterogeneous catalysts; Electrochemical oxidation; Oxidative coupling; Zeolites; Thermochemical processes.

\title{
Short Biographical
}

Bingwen Wang is currently a third year PhD student in the Department of Chemical Engineering and Materials Science at Wayne State University working under the supervision of Professor Eranda Nikolla. She received her BS from Nankai University in 2006, and a MS degree from Eastern Michigan University in 2013. Her PhD dissertation focuses on the development of active/selective heterogeneous catalysts for chemical conversion processes, such as the oxidative coupling of methane.

Sandra Albarracín-Suazo graduated from the National University of Colombia with a BS in Chemical Engineering. She is currently working towards her MS in chemical engineering at the University of Puerto Rico-Mayagüez under the supervision of Professor Yomaira Pagán-Torres. Her research focus is on the low temperature oxidative conversion of methane in metal-exchanged zeolites.

Yomaira Pagán-Torres is an Assistant Professor in the Department of Chemical Engineering at the University of Puerto Rico-Mayagüez. She received her PhD degree from the University of WisconsinMadison in 2011 under the supervision of Professor James A. Dumesic. Prior to her academic position at 
the University of Puerto Rico-Mayagüez, she worked for The Dow Chemical Company as a Senior Engineer of the Hydrocarbons R\&D group in Freeport, Texas. Her research focuses on the design and synthesis of heterogeneous catalytic materials with tailored active sites for the transformation of carbon resources, such as biomass, carbon dioxide, and methane to chemicals and fuels.

Eranda Nikolla is an Assistant Professor in the Department of Chemical Engineering and Materials Science at Wayne State University. She received her $\mathrm{PhD}$ in Chemical Engineering from the University of Michigan in 2009 under the supervision of Prof. Suljo Linic and Prof. Johannes Schwank, followed by a two-year postdoctoral work at California Institute of Technology with Prof. Mark E. Davis. Her research interests lie in the development of heterogeneous catalysts and electrocatalysts for chemical/electrochemical conversion processes, including methane reforming and oxidative coupling of methane using a combination of experimental and theoretical techniques. 


\section{Introduction}

Development of efficient and selective methane conversion processes to electricity, fuels and chemicals has become critical in the recent years due to the emerging number of untapped, unconventional natural gas reserves (e.g., shale gas) and the need to reduced our dependence from limited crude oil resources [1-5]. Recent advancements in hydraulic fracturing have led to access of shale gas reserves that are rich in methane ( $>70 \%$ of the carbon) $[3,5]$. Currently, methane is mostly combusted for generation of electrical power and heat [5]. To date, industrial routes for one-step conversion of methane to fuels and chemicals are limited. The most technologically advanced routes are indirect conversion of methane (i.e., methane steam reforming [6]) to fuels and chemicals. For example, steam reforming involves the generation of $\mathrm{H}_{2}$ and $\mathrm{CO}$ mixtures from methane at high temperatures $\left(700{ }^{\circ} \mathrm{C}\right.$ to $1000{ }^{\circ} \mathrm{C}$ ) and pressures (15 to $\left.40 \mathrm{~atm}\right)$ [5], which are then used in the production of methanol and FischerTropsch synthesis. The challenges associated to the one-step conversion of methane to chemicals and fuels arise from the fact that methane is a very stable molecule, comprised of C-H bonds that are weakly polarized. Hence, very aggressive reactants and operating conditions (e.g., temperature and pressures) are required to activate the methane $\mathrm{C}-\mathrm{H}$ bond, consequently favoring undesired reactions (e.g., complete combustion to $\mathrm{CO}_{2}$ ) which lead to loss in activity, selectivity, and yield of desired products.

The schematic in Fig. 1 illustrates some of the main high- and low-temperature methane conversion processes. As indicated in Fig. 1, high-temperature processes mainly involve the partial or total oxidation of methane to $\mathrm{CO}, \mathrm{H}_{2}$, and $\mathrm{CO}_{2}$ with the exception of oxidative coupling and non-oxidative conversion of methane that lead to the formation of $\mathrm{C}_{2+}$ hydrocarbons [6-12]. While, some of the high temperature processes are technologically advanced, they are energy intensive and high cost [13]. Hence, development of one-step processes for conversion of methane to useful intermediates or fuels and chemicals at lowtemperatures would alleviate some of these challenges. To date, low-temperature processes (Fig. 1) have largely focused on partial/total oxidation of methane to valuable intermediates for synthesis of fuels and chemicals, such as methanol and dimethyl ether. However, most of these processes suffer from limited 
selectivity to targeted products, since under operating conditions most of the products or intermediates are more reactive than methane and undergo further transformation or decomposition. In this short review, we provide an overview of the latest advancements in methane conversion at high- and low-temperatures to fuels, chemicals, and electricity. In addition, we conclude with a perspective on the promises and drawbacks associated with each of these processes.

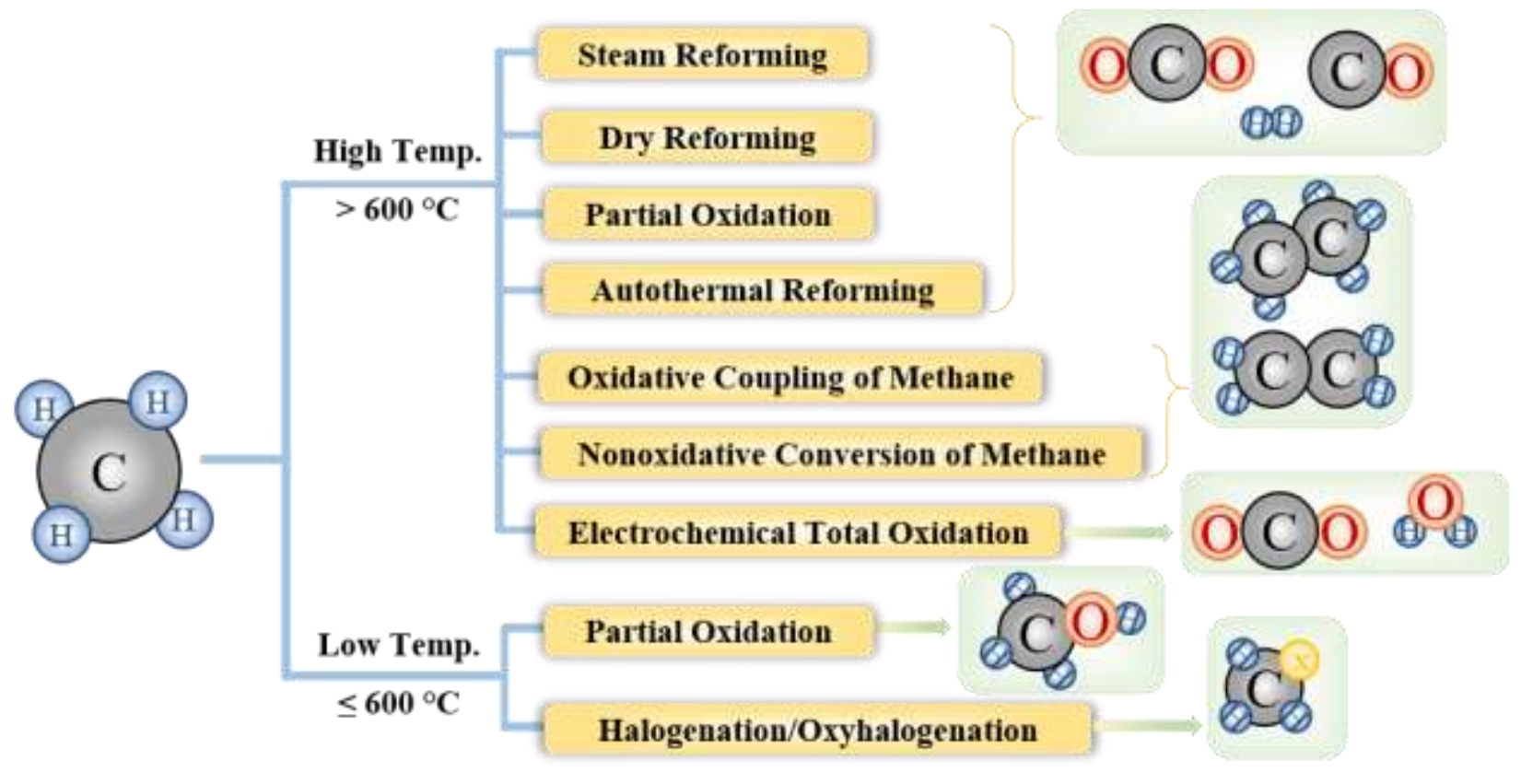

Fig. 1. Schematic of selected methane conversion processes at high- and low-temperatures.

\section{High temperature methane conversion processes}

\subsection{Thermochemical methane oxidation to $\mathrm{CO}$ and $\mathrm{H}_{2}$}

High temperature thermochemical processes for conversion of methane to synthesis gas (a mixture of $\mathrm{CO}$ and $\mathrm{H}_{2}$ ) are the most developed technologies for the production of valuable intermediates. These processes include methane steam reforming, dry reforming, partial oxidation and autothermal reforming. Below, we discuss the advances and challenges associated with steam and dry reforming of methane. In the case of the partial oxidation and autothermal reforming, we refer to the cited reviews [3, 14-16].

Methane Steam Reforming. Steam reforming of methane is the most developed industrial process for generation of $\mathrm{H}_{2}$ from methane. This process involves the conversion of methane and water (steam) into 
$\mathrm{H}_{2}$ and $\mathrm{CO}$ (rxn 1), and is accompanied by the slightly exothermic water gas shift reaction (WGS) (rxn 2), which converts $\mathrm{CO}$ and steam into $\mathrm{CO}_{2}$ and hydrogen.

$$
\begin{array}{llr}
\mathrm{CH}_{4}+\mathrm{H}_{2} \mathrm{O}=\mathrm{CO}+3 \mathrm{H}_{2} & \left(\Delta \mathrm{H}_{298}=206 \mathrm{~kJ} / \mathrm{mol}\right) & \text { rxn 1 } \\
\mathrm{CO}+\mathrm{H}_{2} \mathrm{O} \Leftrightarrow \mathrm{CO}_{2}+\mathrm{H}_{2} & \left(\Delta \mathrm{H}_{298}=-41.2 \mathrm{~kJ} / \mathrm{mol}\right) & \text { rxn 2 }
\end{array}
$$

It is mainly catalyzed by transition metals, with Ni being the most commonly used industrially due to its high activity toward $\mathrm{C}-\mathrm{H}$ bond activation in methane and low cost $[6,9]$. It has been well-established using both experiments and theory that at high operating temperatures of greater than $550{ }^{\circ} \mathrm{C}$, the rate limiting step in methane steam reforming on $\mathrm{Ni}$ is $\mathrm{C}-\mathrm{H}$ bond activation [17-20]. C-H bond activation in methane is surface structure sensitive with Ni under-coordinated edge sites exhibiting a lower energy barrier for this step when compared to the well-coordinated Ni terrace sites. Density functional theory (DFT) studies have also suggested that at lower temperatures $\left(\sim 500{ }^{\circ} \mathrm{C}\right)$ the formation of adsorbed $\mathrm{CO}^{*}$ from adsorbed $\mathrm{C}^{*}$ and $\mathrm{O}^{*}$ atoms $\left(\mathrm{C}^{*}+\mathrm{O}^{*}=>\mathrm{CO}^{*}\right)$ becomes rate limiting for the process [21].

The major challenges with steam reforming of methane using Ni-based catalysts include: (i) catalyst deactivation due to carbon formation, (ii) catalyst deactivation due to impurities in the methane feed, such as sulfur, and (iii) sintering of the Ni particles at high operating temperatures that leads to a decrease in the active surface area, thus lower catalytic activity over time $[22,23]$. The carbon-induced deactivation of $\mathrm{Ni}$ has been studied extensively [6, 9, 22, 24-34]. For example, it has been demonstrated using in-situ transition electron microscopy (TEM) and DFT studies that carbon deposits are formed by the diffusion of carbon atoms on surface of the Ni particles and their subsequent binding to carbon nucleation centers $[27,29]$. These studies also showed that carbon nucleation originated on under-coordinated, edge surface sites of $\mathrm{Ni}$, which as we discussed above are also the most active for $\mathrm{C}-\mathrm{H}$ bond activation [27, 29]. An increase in the concentration of steam in the feed can alleviate this problem by enhancing the rate of carbon oxidation, however, this approach introduces a number of operational challenges, including an 
increase in the operational cost $[6,9]$. Improving the carbon-tolerance of Ni catalysts via promotion with alkaline metals or alloying with other metals have been explored as potential solutions to this challenge [30, 35-42]. A number of efforts that utilize a combined experimental/theoretical approach have been instrumental in determining the mechanism that leads to carbon poisoning, and in proving insights on developing carbon-tolerant catalysts for this process $[6,31,34,43]$. For example, Nikolla and co-workers have shown that alloying $\mathrm{Ni}$ with a small amount of $\mathrm{Sn}$ (forming a $\mathrm{Sn} / \mathrm{Ni}$ surface alloy) can lead to changes in the energetics associated with $\mathrm{C}-\mathrm{O}$ bond formation versus $\mathrm{C}-\mathrm{C}$ bond formation on the surface, consequently effecting the $\mathrm{C}$-induced deactivation of the $\mathrm{Ni}$ catalyst [31]. Fig. 2a shows the reaction energies associated with methane steam reforming on $\mathrm{Ni}(111)$ obtained using DFT calculations [31]. This plot suggests that there are two thermodynamically stable sinks for the adsorbed $\mathrm{C}^{*}$ atoms formed on the $\mathrm{Ni}$ surface from $\mathrm{C}-\mathrm{H}$ bond activation in methane: (i) formation of adsorbed $\mathrm{CO} *$ and then $\mathrm{CO}_{2}$ from the reaction with adsorbed $\mathrm{O}^{*}$ atoms, or (ii) the reaction with other adsorbed $\mathrm{C}^{*}$ atoms on the surface to form extended carbon structures that deactivate the catalyst. Figs. $2 b$ and $2 c$ show that while the paths for formation of $\mathrm{C}-\mathrm{C}$ and $\mathrm{C}-\mathrm{O}$ bond on monometallic $\mathrm{Ni}$ are energetically comparable; this behavior changes when the $\mathrm{Ni}$ surface is modified with $\mathrm{Sn}$ atoms. In the case of $\mathrm{Ni} / \mathrm{Sn}$ surface alloy, the C-C bond formation path becomes less energetically favorable than $\mathrm{C}-\mathrm{O}$ bond formation leading to preferential removal of the $\mathrm{C}$ atoms from the surface forming $\mathrm{CO}$ or $\mathrm{CO}_{2}$ instead of extended carbon structures. Nikolla and co-workers demonstrated experimentally that the $\mathrm{Sn} / \mathrm{Ni}$ surface alloy led to a more carbontolerant catalyst than monometallic Ni during steam reforming of methane [31, 34]. They also showed using energy loss near edge spectroscopy (ELNES), Auger electron spectroscopy (AES) studies along with DFT calculations that the changes in the $\mathrm{C}$ and $\mathrm{O}$ chemistry on $\mathrm{Sn} / \mathrm{Ni}$ alloy surface as compared to monometallic Ni were due to Sn-induced electronic changes on the surface Ni atoms, in addition to the Sn-induced geometric effects (breaking the surface ensembles of the Ni particles) [44]. These studies clearly demonstrate that the utilization of the combined experimental/theoretical approaches has been instrumental at obtaining fundamental insights regarding the process of methane steam reforming and in devising ways to improve the activity and stability of steam reforming catalysts. 

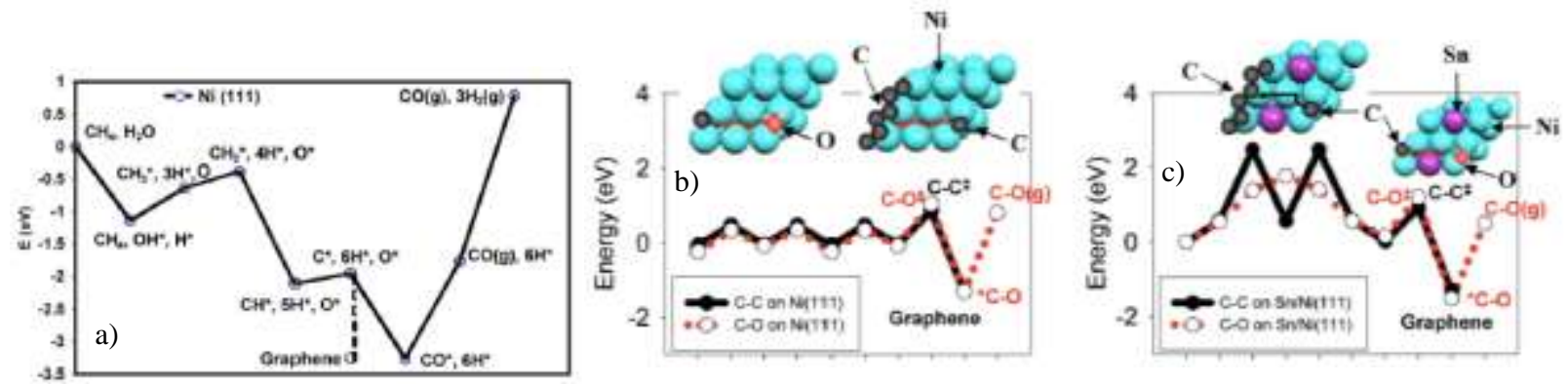

Fig. 2. a) Reaction energies for the elementary steps associated with steam reforming of methane on $\mathrm{Ni}(111)$ obtained using DFT calculations. b) Potential energy surfaces for $\mathrm{C}-\mathrm{C}$ and $\mathrm{C}-\mathrm{O}$ bond formation on $\mathrm{Ni}(111)$. c) Potential energy surfaces for $\mathrm{C}-\mathrm{C}$ and $\mathrm{C}-\mathrm{O}$ bond formation on $\mathrm{Sn} / \mathrm{Ni}(111)$ alloy. Inserts show the lowest energy pathways for attachment of a $\mathrm{C}$ atom to an $\mathrm{O}$ atom (in the case of $\mathrm{C}-\mathrm{O}$ bond formation) and the attachment of a $\mathrm{C}$ atom to a carbon nucleation center (modeled as a chain of carbon atoms). Ni is shown as a large blue (light) atom, $\mathrm{Sn}$ as a large magenta atom, oxygen as a small red atom, while carbon as small black atoms. Red lines and letters correspond to $\mathrm{O}$ diffusion and the $\mathrm{C}-\mathrm{O}$ bond formation, while black lines and letters correspond to $\mathrm{C}$ diffusion and the $\mathrm{C}-\mathrm{C}$ bond formation. Reprinted from ref [31]. Reproduced with the permission from Elsevier.

While above we mainly discuss the advances related to Ni-based catalysts for steam reforming of methane due to several advantages that Ni provides for this process, a number of studies over the years have explored the activity of different transition metals for this process [10, 21, 45-49]. It has been shown that most of the pure metals that exhibit superior steam reforming activity to $\mathrm{Ni}$ are fairly expensive (e.g., $\mathrm{Ru}, \mathrm{Rh})$ making their industrial implementation economically challenging.

Methane Dry Reforming. Dry reforming of methane is another important process that involves the reaction of $\mathrm{CH}_{4}$ with an abundant greenhouse gas, $\mathrm{CO}_{2}$, to generate synthesis gas (rxn 3).
$\mathrm{CH}_{4}(\mathrm{~g})+\mathrm{CO}_{2}(\mathrm{~g})=>2 \mathrm{CO}+2 \mathrm{H}_{2}(\mathrm{~g})$
$\left(\Delta \mathrm{H}_{298}=247 \mathrm{~kJ} / \mathrm{mol}\right)$
rxn 3

It is highly endothermic and commonly catalyzed by transition metals supported on oxides. The mechanism of methane dry reforming has been studied by many $[10,50,51]$. It has been established that the rate-limiting step in this process is $\mathrm{C}-\mathrm{H}$ bond activation in methane, which occurs on the transition metal [50]. In the case of $\mathrm{C}-\mathrm{O}$ bond activation in $\mathrm{CO}_{2}$, it has been suggested that if the metal is supported on basic or acidic oxide supports it occurs on the oxide, while on more neutral supports the activation of 
C-O bond takes place on the metal. On metals, $\mathrm{C}-\mathrm{O}$ bond activation occurs with a lowest energy barrier on surface defect sites, such as steps. In the case of metals supported on acidic or basic oxides the mechanism of $\mathrm{C}-\mathrm{O}$ bond activation depends on the nature of the support [12]. For example, it has been reported that on acidic supports $\mathrm{CO}_{2}$ dissociative adsorption occurs via the formation of formates, while on basic supports it has been suggested that the mechanism involves the formation of oxy-carbonates [12, 51].

The main challenge with dry reforming of methane is the deactivation of the catalyst due to carbon poisoning. It has been suggested that the deactivation of the metal catalyst is more pronounced in the case when metals are supported on neutral supports, since both the $\mathrm{C}-\mathrm{H}$ bond activation in methane and $\mathrm{C}-\mathrm{O}$ bond activation in $\mathrm{CO}_{2}$ occur on the metal surface [52]. The use of basic supports or promoters, such as $\mathrm{CeO}_{2}$ and $\mathrm{La}_{2} \mathrm{O}_{3}$, has shown to minimize carbon formation by (i) facilitating dissociation of $\mathrm{CO}_{2}$ with low energy barriers through the formation of oxy-carbonates, and (ii) providing surface oxygen atoms for facilitating the removal of the surface $\mathrm{C}$ atoms formed during $\mathrm{C}-\mathrm{H}$ bond activation in methane [52, 53]. Another approach to suppress carbon formation is to synthesize very small metal particles that are well dispersed on the support [10]. A critical, minimum metal particle size is required for the formation of extended carbon structures. Therefore, synthesizing very small, well-dispersed metal particles destabilizes the formation of extended carbon structures and also enhances the interaction between the support and the metal, increasing the probability of the $\mathrm{O}$ atoms formed from $\mathrm{CO}_{2}$ dissociation on the support to oxidize the $\mathrm{C}$ atoms on the metal formed from methane dissociation [10]. While there have been many attempts to minimize carbon formation through the routes discussed above; it still remains a significant challenge for the industrial implementation of the process.

\subsection{Oxidative coupling and nonoxidative conversion of methane}

Oxidative Coupling of Methane (OCM) with Molecular Oxygen in Packed Bed Reactors. Oxidative coupling of methane has been explored for many years as a potential route for synthesis of $\mathrm{C}_{2+}$ hydrocarbons, such as ethylene, directly from methane in the presence of oxygen [54-76]. This process was first reported in the early 1980 by Keller and Basin [7] along with Hinsen and Bearns [8], who 
demonstrated direct synthesis of ethylene from methane and oxygen steams at elevated temperatures of greater than $500{ }^{\circ} \mathrm{C}$ on oxide catalysts. A detailed mechanism for this process was reported by Lunsford [11] and involved the activation of the first $\mathrm{C}-\mathrm{H}$ bond in methane through the active oxygen atoms on the catalytic surface, leading to the formation of methyl free radicals $\left(\mathrm{CH}_{3}{ }^{*}\right)$. The methyl radicals were then coupled to form ethane, followed by subsequent dehydration to form ethylene. This process has been widely explored since the early $80 \mathrm{~s}$, but inherent limitations in achieving high yields to $\mathrm{C}_{2+}$ products have been reported [77, 78]. The limited high selectivities at high conversions are due to the high thermodynamic stability of undesired side products, such as $\mathrm{CO}_{2}$ and solid carbon, and also to the fact that most heterogeneous catalysts that activate $\mathrm{C}-\mathrm{H}$ bonds in methane at high rates are also very active toward the activation of the $\mathrm{C}-\mathrm{H}$ bonds in ethane $[77,78]$. As such an inherent barrier for ethylene yields of $30 \%$ has been predicted [77]. Theoretical studies have been conducted to elucidate the mechanism of OCM on various metal oxides. It has been shown that an optimal catalyst for this process has to provide a compromise between the energetics associated with $\mathrm{C}-\mathrm{H}$ bond activation and methyl radical adsorption $[54,79]$. Theoretical studies by Janik and coworkers [54] showed that the reducibility of mixed metal oxides played a key role in providing a "tradeoff" between these steps during OCM.

Fig. 3 summarizes some of the best performing catalysts [80] (mainly doped and mixed metal oxides) reported for this reaction. The highest selectivities are reported for Li-doped oxide catalysts. While promising, Li-doped oxides suffer from loss of $\mathrm{Li}$ under reaction conditions, which leads to loss in performance over time rendering them unstable for long-term operation under OCM conditions [57, 66, $69,73,74]$.

In addition to molecular oxygen, sulfur has also been used as a "softer" oxidizer for this reaction [81]. DFT calculations were used to identify metal sulfide catalysts that provided the best compromise between the energetics associated with $\mathrm{C}-\mathrm{H}$ bond activation in methane and $\mathrm{CH}_{2}$ coupling. While the DFT predicted PbS-based catalysts were shown to exhibit the highest selectivity among the metal sulfides considered; the selectivity was lower than some of the best performing catalysts reported for oxidative coupling of methane with molecular oxygen shown in Fig. 3. 


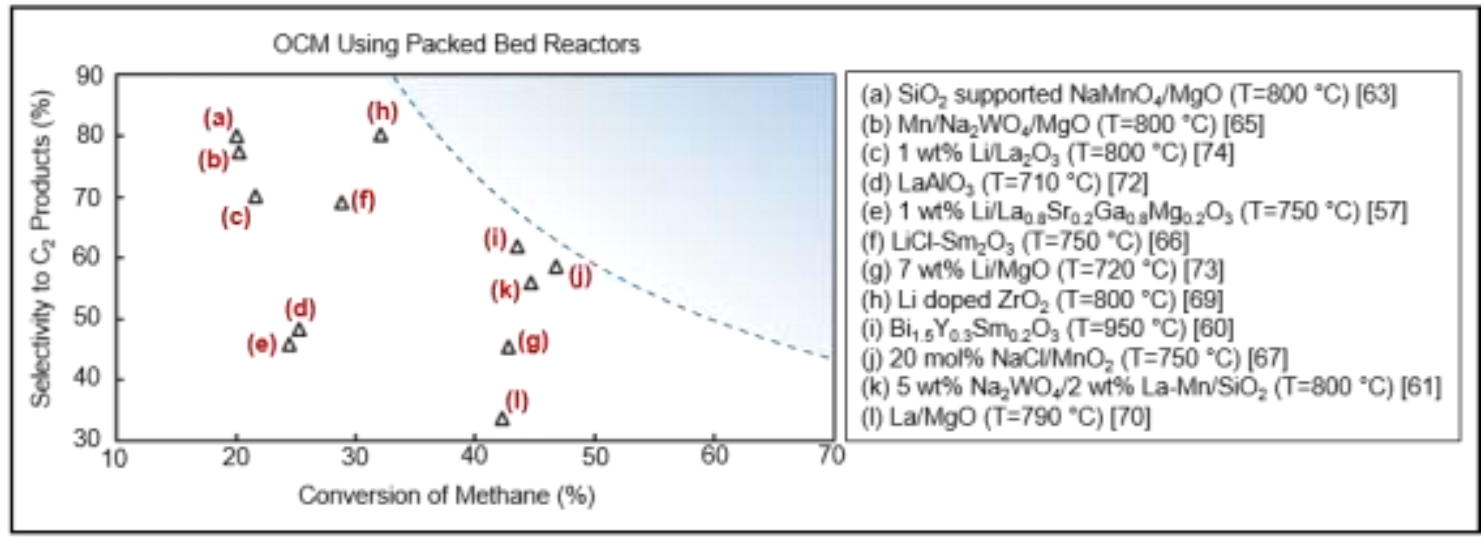

Fig. 3. Plot showing the published data (from references $[57,60,61,63,65-67,69,70,72-74]$ ) for methane conversion versus the selectivity to $\mathrm{C}_{2+}$ products on different metal oxide catalysts operated in packed bed reactors. The blue shaded region shows the region appropriate for industrial standards.

OCM with Oxygen Ions through Membrane Reactors. An approach to overcome some of the limitations associated with OCM using molecular oxygen is to implement oxygen ion conducting membranes that control the amount of oxygen that is available to react with methane $[78,82,83]$. In these systems, molecular oxygen and methane are fed on two different sides of an oxygen conducting membrane. On one side of the membrane, oxygen reduction takes place forming oxygen ions $\left(\mathrm{O}^{2-}\right)$ on the oxide, which diffuse to the other side to react with methane. Oxygen ion conduction can be achieved spontaneously at elevated temperatures due to the difference in the oxygen partial pressure on the different sides of the membranes, or it can be controlled via electrochemical pumping, which involves utilization of an outside power sources to direct the amount of charged species through the membrane [82].

Control over the oxygen partial pressure on the methane side of the membrane reactor is critical in achieving high $\mathrm{C}_{2+}$ selectivities, since it has been shown that there is a $1 / 2$ order $\mathrm{O}_{2}$ dependence in the case of reaction steps that lead to $\mathrm{C}_{2+}$ products, and a first order $\mathrm{O}_{2}$ dependence for complete oxidation steps that leads to the undesired formation of $\mathrm{CO}_{2}$ [78]. Hence, by controlling the partial pressure of oxygen (e.g., operating at low partial pressures) one can favor the formation of $\mathrm{C}_{2+}$ products over the complete oxidation to undesired products. Based on this, one would anticipate that membrane reactors would lead to higher selectivities than OCM catalysts in packed bed reactors with molecular oxygen. In general, 
while high $\mathrm{C}_{2+}$ selectivities have been reported for OCM membrane reactors, they suffer from lower conversions (Fig. 4) when compared to packed bed reactor systems (Fig. 3) [78]. This is due to several factors, including the fact that most literature reports have focused on using standard oxygen conducting oxides that are relatively thick and exhibit limited oxygen conduction rates unless operated at very high temperatures $\left(>800^{\circ} \mathrm{C}\right)$ [82]. Improvements in the performance of membrane reactors can be achieved by using thinner and more efficient oxygen ion conducting oxides, higher surface area membranes [71], and also by controlling the oxygen flux through the membrane using an external power source. Wang and Nikolla are currently exploring the use of mixed ionic/electronic, layered Ruddlesden-Popper oxides [84] as potentially high oxygen conducting membranes, and efficient oxygen reduction and $\mathrm{C}-\mathrm{H}$ bond activation catalysts for OCM.

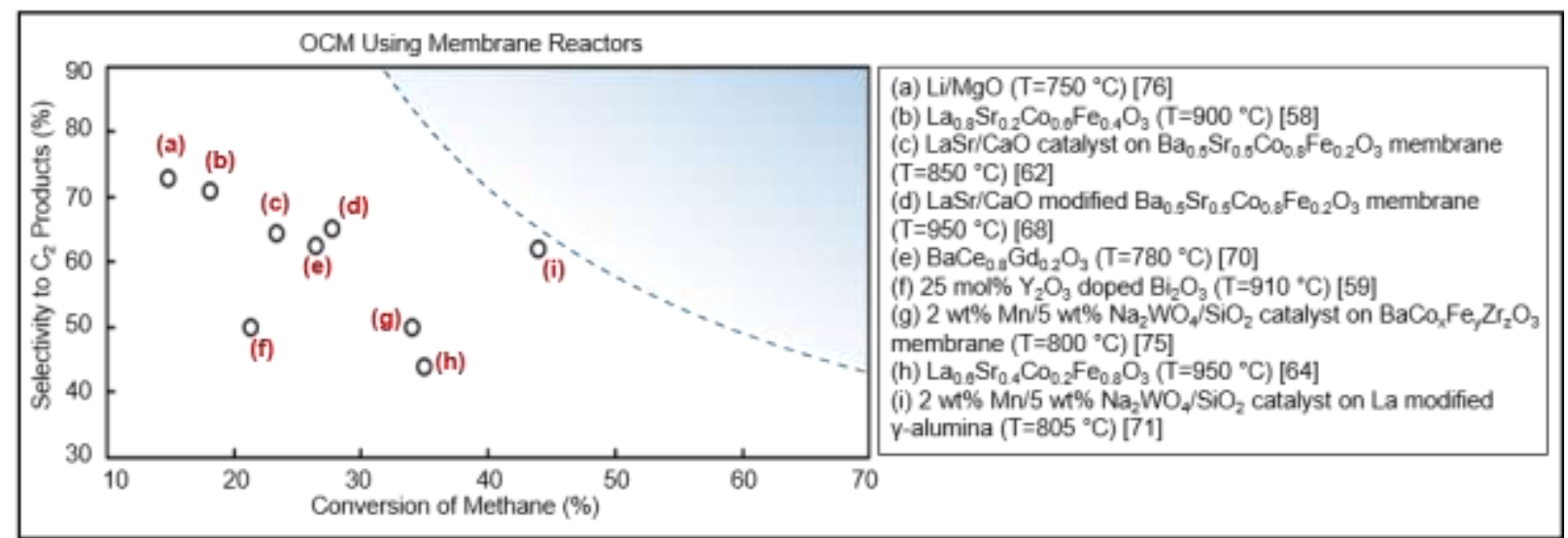

Fig. 4. Plot showing the published data (from references $[58,59,62,64,68,70,71,75,76]$ ) on methane conversion versus the selectivity to $\mathrm{C}_{2+}$ products on different membrane reactors. The blue shaded region shows the region appropriate for industrial standards.

While there have been a number of advancements in packed bed and membrane reactor systems for OCM, operation within the industrial standards (blue regions in Fig. 3 and 4) is still a challenge for most of the systems reported.

Nonoxidative Conversion of Methane. Nonoxidative conversion of methane to ethylene, aromatics and hydrogen at high temperatures is considered to be another direct route for conversion of methane to useful chemicals and fuels [85]. The advantage of nonoxidative conversion of methane is that it prevents irreversible overoxidation, which leads to thermodynamically stable undesired products, such as $\mathrm{CO}_{2}$ and 
$\mathrm{H}_{2} \mathrm{O}$. Fe and Mo supported on zeolites have shown promising selectivities to hydrocarbon (e.g., naphthalene) formation during this process [85-87]. The proposed mechanism involves $\mathrm{C}-\mathrm{H}$ bond activation in methane on the metal sites forming $\mathrm{CH}_{\mathrm{x}}$ species followed by dimerization to $\mathrm{C}_{2} \mathrm{H}_{\mathrm{y}}$. While, nonoxidative coupling of methane is advantageous since it eliminates the formation of $\mathrm{CO}_{2}$, a greenhouse gas, coke formation on the catalyst surface and the relatively high reaction temperatures as compared to oxidation processes are still a challenge.

\section{Low temperature methane conversion processes}

The development of processes for the partial oxidation of methane to methanol through a lowtemperature direct route from an inexpensive and abundant feedstock is a long-standing challenge, stimulated by the numerous applications of the chemical as a solvent and a precursor for the production of commodity chemicals, such as formaldehyde, methyl tert-butyl ether, acetic acid, chloromethanes, methyl methacrylate $[88,89]$. Current industrial methanol synthesis from methane involves a high-temperature and energy-intensive process involving the formation of synthesis gas by autothermal reforming, followed by the conversion of the synthesis gas to methanol over $\mathrm{Cu} / \mathrm{ZnO} / \mathrm{Al}_{2} \mathrm{O}_{3}$ catalysts $[90,91]$. Although the current industrial process produces methanol in high yields it requires high temperatures and pressures at various stages, in addition to large-capital intensive reforming facilities [90, 91], which limit the implementation of this technology in remote and inconveniently located untapped natural gas reserves [90]. Therefore significant interest in the development of direct low-temperature methane to methanol processes, that circumvent the production of synthesis gas, has emerged to exploit the transformation of abundant and remotely located sources of natural gas [92]. Inspired by the remarkable activity and selectivity of methanotrophic bacteria to convert methane at mild reaction conditions over methane monooxygenase enzymes (MMO) [93-96], transition metal-exchanged zeolites, with active sites analogous to those in MMO have been studied as reactive materials for the activation of the highly stable

$\mathrm{C}-\mathrm{H}$ bond $\left(438.8 \mathrm{~kJ} \mathrm{~mol}^{-1}\right)$ of methane at low temperatures $\left(<250{ }^{\circ} \mathrm{C}\right)$ [97-99]. The active site of these enzymes for methane oxidation have been elucidated as bis( $\mu$-oxo)diiron complexes in soluble methane 
monooxygenase (sMMO) and as bis( $\mu$-oxo)dicopper complexes in particulate methane monooxygenase (pMMO) $[93,100]$.

The first efforts in developing inorganic heterogeneous materials for the oxidation of methane to methanol, with active sites similar to sMMO enzymes, were Fe-ZSM-5 zeolites activated with nitrous oxide $\left(\mathrm{N}_{2} \mathrm{O}\right)$ [101, 102]. The $\mathrm{N}_{2} \mathrm{O}$ assisted in the formation of an active bridging Fe-oxo complex for hydrogen atom abstraction from methane $[101,102]$. A bis( $\mu$-oxo)diiron cluster similar to the active center in sMMO was elucidated by in-situ Mossbauer spectroscopy studies of Fe-exchanged ZSM-5 [103]. In addition to Fe-exchanged zeolites, Cu-exchanged ZSM-5 has received considerable interest for methane oxidation to methanol. The elucidation of the active $\mathrm{Cu}$ species in ZSM-5 has been subject of numerous spectroscopic and theoretical studies [104-106]. Pioneering work on Cu-exchanged ZSM-5 was conducted by Groothaert et al., which demonstrated the partial oxidation of methane by a stepwise and stoichiometric reaction with molecular oxygen at low temperatures [104]. A bis( $\mu$-oxo)dicopper complex has been proposed as the active site by a number of studies [104, 105, 107], however some have identified the site by resonance Raman spectroscopy and DFT studies as a bent mono-( $\mu$-oxo)dicopper cluster located at the intersection of two 10-membered rings [108, 109].

Although a number of Cu-oxo species in ZSM-5 have been identified as active sites for methane oxidation to methanol, most suggested species are comprised of more than one $\mathrm{Cu}$ atom [97]. In a very recent work, a comprehensive theoretical study based on DFT and ab initio thermodynamic analysis was conducted by $\mathrm{Li}$ et al. on the structure, stability, and reaction mechanism of extra-framework $\mathrm{Cu}$ complexes in ZSM-5 (e.g., bi- and trinuclear $\mathrm{Cu}$-oxo species) as a function of activation and reaction conditions [110]. The formation of extra-framework trinuclear Cu-oxo species in $\mathrm{ZSM}-5,\left[\mathrm{Cu}_{3}(\mu-\mathrm{O})_{3}\right]^{2+}$, was shown to take place under oxygen-rich environments at high temperatures, whereas the formation of binuclear $\mathrm{Cu}$ species, $[\mathrm{Cu}(\mu-\mathrm{O}) \mathrm{Cu}]^{2+}$, are formed and stabilized in low oxygen partial pressure environments during catalyst activation. Theoretical studies indicated that both the binuclear $\mathrm{Cu}$ complex $[\mathrm{Cu}(\mu-\mathrm{O}) \mathrm{Cu}]^{2+}$ and trinuclear $\mathrm{Cu}-\mathrm{complex}\left[\mathrm{Cu}_{3}(\mu-\mathrm{O})_{3}\right]^{2+}$ were reactive for $\mathrm{C}-\mathrm{H}$ bond activation, however 
the trinuclear $\mathrm{Cu}$-complex exhibited the lowest energy pathway as shown in Fig. 5 [110]. It is important to note that after reaction, the trinuclear $\mathrm{Cu}$-species $\left[\mathrm{Cu}_{3}(\mu-\mathrm{O})_{3}\right]^{2+}$ was transformed to a partially reduced $\mathrm{Cu}$ complex, $\left[\mathrm{Cu}_{3}(\mu-\mathrm{O})_{2}\right]^{2+}$, hence regeneration of the active site was essential for the next methane conversion cycle [110].

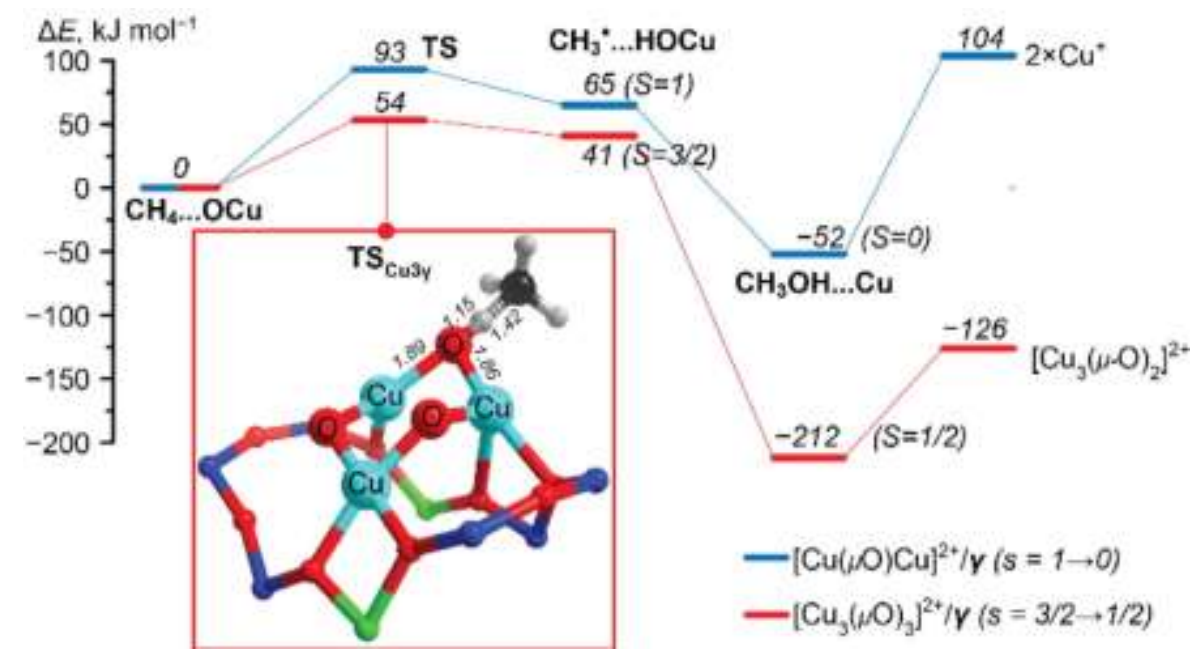

Fig. 5. Minimum reaction energy paths for methane conversion to methanol over binuclear $\mathrm{Cu}$-oxo complex, $[\mathrm{Cu}(\mu$ $\mathrm{O}) \mathrm{Cu}]^{2+}$, and the trinuclear Cu-oxo complex, $\left[\mathrm{Cu}_{3}(\mu-\mathrm{O})_{3}\right]^{2+}$, in Cu-ZSM-5. Reprinted from ref [110], Copyright 2016, with permission from Elsevier.

Markovits et al. studied the effect of the location and distribution of Al sites in ZSM-5 on the formation of $\mathrm{Cu}-\mathrm{oxo}$ species to understand the structure and chemical environment required for the stabilization of these active sites [111]. A number of $\mathrm{Cu}-\mathrm{ZSM}-5$ materials with high concentrations of $\mathrm{Al}$ pairs and different loadings of $\mathrm{Cu}$ were synthesized and studied in the stepwise oxidation of methane to methanol. From a combination of IR spectroscopy, extended X-ray absorption fine structure (EXAFS) studies, and DFT computed geometrical parameters of $\mathrm{Cu}$-oxo complexes [110], the authors proposed structures for the $\mathrm{Cu}$-oxo complexes in ZSM-5. Trinuclear $\mathrm{Cu}$-oxo complexes $\left[\mathrm{Cu}_{3}(\mu-\mathrm{O})_{3}\right]^{2+}$ bonded to two paired framework $\mathrm{Al}$ as active sites for $\mathrm{Cu}$-exchanged $\mathrm{ZSM}-5$ for $\mathrm{Cu} / \mathrm{Al}$ ratios of 0.2 to 0.5 and a combination of $\mathrm{Cu}$ monomers and dimers $\left[\mathrm{Cu}_{2}(\mu-\mathrm{O})\right]^{2+}$ for $\mathrm{Cu} / \mathrm{Al}$ ratios below 0.2 were proposed [111]. The highest yield obtained for methane oxidation was of $89 \mu \mathrm{mol} \mathrm{g}_{\mathrm{cat}}{ }^{-1}$ over Cu-ZSM-5 catalyst with 
$\mathrm{Cu} / \mathrm{Al}$ ratios of approximately 0.5 . Although the synthesized zeolites by Markovits et al. displayed high yields for methane oxidation, it should be noted that only $50 \%$ of the sites were active [111]. In addition to the nature of the extra-framework $\mathrm{Cu}$-oxo cluster, it was concluded that the size and shape of the zeolite environment where the embedded $\mathrm{Cu}$ cluster is localized impacts its reactivity in methane conversion.

Interestingly, $\mathrm{Cu}$-oxo species in other zeolite frameworks such as mordenite (MOR) have demonstrated higher methanol yields for the oxidation of methane compared to Cu-exchanged H-ZSM-5 materials [112]. Vanelderen et al. conducted detailed Raman spectroscopy studies to elucidate the structure of $\mathrm{Cu}$ active sites in MOR [113]. The sites were identified as two different $\left[\mathrm{Cu}_{2} \mathrm{O}\right]^{2+}$ clusters located in the 8-membered ring (MR) side pockets of MOR [113]. Depending on the framework environment in which the $\left[\mathrm{Cu}_{2} \mathrm{O}\right]^{2+}$ sites were located, differences in methane oxidation reactivity were observed [113]. Besides $\left[\mathrm{Cu}_{2} \mathrm{O}\right]^{2+}$ clusters being identified as active species for methane conversion, trinuclear $\mathrm{Cu}$-oxo species in MOR have recently demonstrated high reactivity for $\mathrm{C}-\mathrm{H}$ bond activation [112]. The combination of in-situ X-ray adsorption spectroscopy (XAS) and DFT calculations determined the active site as a trinulcear $\mathrm{Cu}$-oxo cluster, $\left[\mathrm{Cu}_{3}(\mu-\mathrm{O})_{3}\right]^{2+}$, bonded to two $\mathrm{Al}$ atoms located at the entrance of the 8-MR side pocket. The barrier for methane $\mathrm{C}-\mathrm{H}$ bond activation of $74 \mathrm{~kJ} \mathrm{~mol}^{-1}$ was determined for the $\left[\mathrm{Cu}_{3}(\mu-\mathrm{O})_{3}\right]^{2+}$ complex in MOR, comparable to the $78 \mathrm{~kJ} \mathrm{~mol}^{-1}$ barrier obtained for methane $\mathrm{C}-\mathrm{H}$ bond activation over binuclear $[\mathrm{Cu}(\mu-\mathrm{O}) \mathrm{Cu}]^{2+}$ complex in ZSM-5 [112]. On the other hand, Zhao et al. performed DFT studies on the formation and reactivity of extra-framework $[\mathrm{CuOCu}]^{2+}$ and $[\mathrm{CuOOCu}]^{2+}$ complexes as active centers in MOR for methane to methanol oxidation [114]. Results suggested that the $[\mathrm{CuOCu}]^{2+}$ complex is the most stable to be formed in MOR and is also the most reactive in activating methane between the two moieties studied [114].

Grundner et al. optimized the synthesis of Cu-exchanged MOR zeolites for the deposition of a high number of uniform trinuclear $\mathrm{Cu}$ complexes in $\mathrm{H}-\mathrm{MOR}$ resembling the structure and reactivity of active sites in pMMO, while minimizing the formation of $\mathrm{Cu}$ spectators [115]. Heterogeneous speciation of $\mathrm{Cu}$ 
(e.g., tri-, di-, and mononuclear species) in MOR was shown to be affected by synthesis conditions, including solution $\mathrm{pH}$ and the cation in the parent zeolite. The presence of $\mathrm{Na}^{+}$and other alkaline earth cations in the 8-MR side pockets were shown to hinder the formation of trinuclear $\mathrm{Cu}$-oxo species. For $\mathrm{Cu}$-exchanged $\mathrm{H}-\mathrm{MOR}$ a stoichiometry of $3: 1 \mathrm{Cu}$ to activated methane confirmed that all extraframework trinuclear $\mathrm{Cu}$-oxo species formed were reactive for methane conversion. Despite that fact that a similar trinuclear $\mathrm{Cu}$-oxo complex $\left[\mathrm{Cu}_{3}(\mu-\mathrm{O})_{3}\right]^{2+}$ has been identified in both $\mathrm{Cu}-\mathrm{H}-\mathrm{MOR}$ and $\mathrm{Cu}-\mathrm{H}-$ ZSM-5, the methane oxidation activity of Cu-H-ZSM-5 is almost 50\% that of Cu-H-MOR [111]. It has been hypothesized that in $\mathrm{H}-\mathrm{ZMS}-5$ the $\mathrm{Cu}$-oxo species are located in more than one environment and in some cases the $\left[\mathrm{Cu}_{3}(\mu-\mathrm{O})_{3}\right]^{2+}$ is in a less constrained local environment exhibiting higher free energy barrier for $\mathrm{C}-\mathrm{H}$ bond activation. Whereas in $\mathrm{Cu}-\mathrm{H}-\mathrm{MOR}$, most of the $\left[\mathrm{Cu}_{3}(\mu-\mathrm{O})_{3}\right]^{2+}$ complexes are stabilized in a highly constrained local environment in the 8-MR side pockets with a lower free energy barrier [111-113].

Besides MFI and MOR, other zeolite topologies such as ferrierite [104], Beta [104], Y [104], SSZ-13 [116], SSZ-16 [116], SSZ-39 [116], and SAPO-34 [116] exchanged with Cu have shown methane oxidation activity to methanol. Smeets et al. demonstrated that $\mathrm{Cu}$-Beta and $\mathrm{Cu}$-ferrierite are reactive materials containing active copper species different to those identified in Cu-MOR and Cu-ZSM-5 zeolites [104]. Cu-exchanged in 8-MR small pore zeolites (e.g., Cu-SSZ-13, Cu-SSZ-16, Cu-SSZ-39, CuSAPO-34) synthesized by Wulfers et al. produced higher methanol per $\mathrm{Cu}$ atom yields in comparison to Cu-ZSM-5 and Cu-MOR [116]. Kulkarni et al. investigated the active site in Cu-SSZ-13 through DFT calculations. A mono-copper species $\left[\mathrm{Cu}^{\mathrm{II}} \mathrm{OH}\right]^{+}$was proposed based on their results and previously reported spectroscopic and experimental studies [117]. Furthermore, the need of water for methanol extraction and the effect of the $\mathrm{Si} / \mathrm{Al}$ ratio of $\mathrm{Cu}-\mathrm{SSZ}-13$ on reactivity were investigated by ab-initio molecular dynamics simulations. The presence of extra water molecules for the extraction of intermediate species was shown to hydrate the $\mathrm{Cu}$ atom, causing the detachment of a $\left[\mathrm{Cu}-2\left(\mathrm{H}_{2} \mathrm{O}\right)-\mathrm{CH}_{3}\right]^{+}$species from 
the framework $\mathrm{Al}$ [117]. The authors proposed that the formation of the mobile hydrated-Cu species gave a possible alternative route for methanol extraction through a more favorable energy path.

Ni-ZMS-5 [118], Co-ZSM-5 [119, 120], and Zn-ZSM-5 [121, 122] have also shown reactivity in the oxidation of methane to methanol with molecular oxygen. Shan et al. have reported that Ni-ZSM-5 converts methane with molecular oxygen to a mixture comprised of methanol, formaldehyde, and ethylene glycol at $150{ }^{\circ} \mathrm{C}$ and atmospheric pressure [118]. The total oxygenated product yield was of 14.9 $\mu \mathrm{mol} \mathrm{g}_{\mathrm{cat}}^{-1}$ [118]. Based on UV-vis, XANES, and EXAFS studies, the nature of the active site was proposed as a bent mono( $\mu$-oxo)dinickel species. The oxidation of methane to a mixture of oxygenates, methanol and formaldehyde, has also been observed for Co-ZSM-5 materials using air [120]. The product distribution was strongly dependent on the nature of the active Co center and the synthesis method conditions. Co-oxide particles (e.g., $\mathrm{CoO}, \mathrm{Co}_{3} \mathrm{O}_{4}$ ) deposited by impregnation favored the formation of methanol, whereas cobalt present in ion-exchange sites favored the formation of formaldehyde. Beznis et al. were able to increase the selectivity of Co-ZSM-5 towards methanol production by altering the microand meso-porosity of the parent ZSM-5 material by alkaline treatments, with the aim of depositing higher loadings of Co-oxide species [120]. Zn modified zeolites, such as ZSM-5, can also activate $\mathrm{CH}_{4}$ at low temperatures through hemolytic and heterolytic mechanisms. Xu et al. studied the room temperature activation of methane over Zn-ZSM-5 by solid-state NMR, spectroscopy studies, and DFT calculations [121]. Dinuclear Zn-oxo species were shown to favor the homolytic cleavage of the methane C-H bond, whereas, the isolated $\mathrm{Zn}^{2+}$ favored the heterolytic cleavage of methane. Hence, surface bound methoxy and zinc methyl species were formed upon $\mathrm{C}-\mathrm{H}$ bond activation on the two different types of active sites. Extraction with water of the surface bound methoxy species in Zn-ZSM-5 led to the successful formation of methanol. Pagán-Torres and Albarracín-Suazo are analyzing, through DFT calculations and experimental studies, the formation, stability, and reactivity of $\mathrm{Zn}^{2+}$ and dinuclear $\mathrm{Zn}$-oxo complexes in different zeolite topologies for the direct oxidation of methane to methanol. 
Numerous research groups in recent years have developed first row transition metal-exchanged zeolites for the direct oxidation of methane to methanol stepwise and stoichiometrically with molecular oxygen $[97,98,123-125]$. For most of these processes the treatment of the exchanged zeolite and the direct oxidation of methane requires three stages consisting of: (i) the oxidation of the transition metal exchanged zeolite with oxygen at high temperatures $\left(\geq 400^{\circ} \mathrm{C}\right)$, (ii) the addition of methane for $\mathrm{C}-\mathrm{H}$ bond activation at low temperatures $\left(<250{ }^{\circ} \mathrm{C}\right)$, and (iii) the introduction of a solvent (e.g., water) for the extraction of surface-bound intermediates to yield methanol [126]. A significant disadvantage of these systems is that after extraction of surface-bound intermediates the sites deactivate, hence requiring high temperature treatments for site regeneration for the subsequent methane oxidation cycle. Furthermore, studies by Bozbag et al. have shown that the long-term performance of $\mathrm{Cu}$-exchanged zeolites (e.g., $\mathrm{Cu}$ MOR) requires more than one complete reaction cycle to obtain maximum methanol yields from methane oxidation [127].

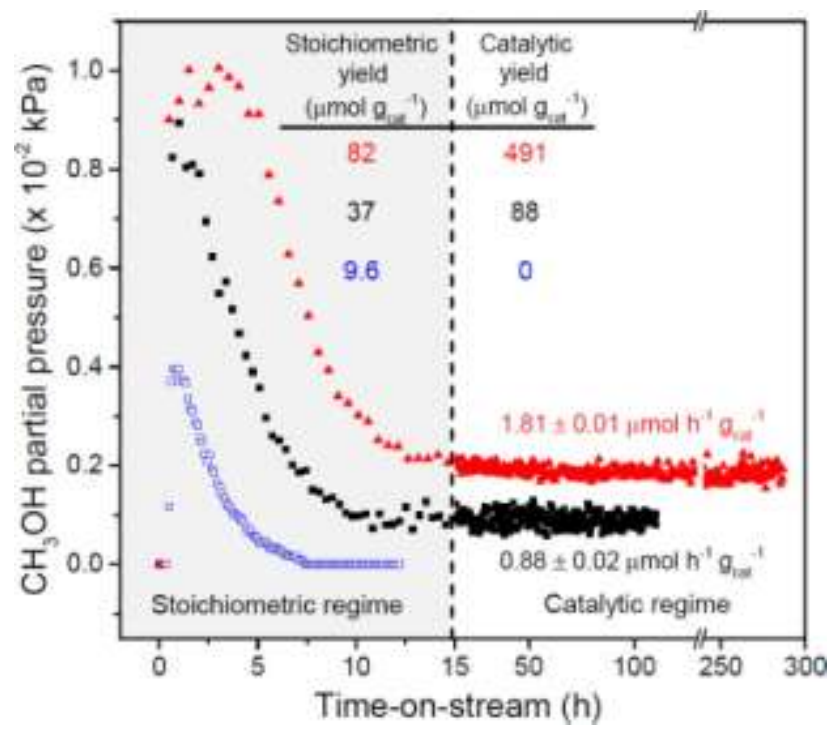

Fig. 6. Stoichiometric and catalytic oxidation regimes for methane to methanol over Cu-Na-ZSM-5 and Cu-H-ZSM5. Catalysts were pretreated and contacted with a flow of methane for reaction, followed by the introduction of a mixture of $\mathrm{He} / \mathrm{H}_{2} \mathrm{O} / \mathrm{O}_{2}$ for the stoichiometric production of methanol over $\mathrm{Cu}-\mathrm{Na}-\mathrm{ZSM}-5$ (blue open squares) or the introduction of a continuous feed of a $\mathrm{CH}_{4} / \mathrm{H}_{2} \mathrm{O} / \mathrm{O}_{2}$ mixture over $\mathrm{Cu}-\mathrm{Na}-\mathrm{ZSM}-5$ (black solid squares) and $\mathrm{Cu}-\mathrm{H}-$ ZSM-5 (red solid triangles). Reprinted with permission from ref [128]. Copyright (C) 2016 American Chemical Society.

To overcome this challenge, in very recent work, Román-Leshkov et al. developed the first catalytic direct oxidation of methane to methanol process using molecular oxygen at low temperatures (210-225 
${ }^{\circ} \mathrm{C}$ ) and atmospheric pressure over $\mathrm{Cu}$-exchanged zeolites [128]. The $\mathrm{Cu}$-exchanged zeolites (e.g., $\mathrm{H}$ ZSM-5, H-Beta, MCM-41, H-mordenite, H-ferrierite, Na-ZSM-5, Na-Y, Na-SAPO-34, Na-SSZ-13) studied were subjected to an initial catalyst pretreatment, followed by introduction of pure methane for $0.5 \mathrm{hr}$, and a subsequent continuous feed of a gas mixture comprised of water, oxygen, and methane [128]. Production rates for the stable and continuous production of methanol were $0.88 \mu \mathrm{mol} \mathrm{h}^{-1} \mathrm{~g}_{\mathrm{cat}}^{-1}$ and $1.81 \mu \mathrm{mol} \mathrm{h}{ }^{-1} \mathrm{~g}_{\text {cat }}{ }^{-1}$ for Cu-Na-ZSM-5 $(\mathrm{Cu} / \mathrm{Al}=0.37)$ and $\mathrm{Cu}-\mathrm{H}-\mathrm{ZSM}-5(\mathrm{Cu} / \mathrm{Al}=0.31)$, respectively as shown in Fig. 6 [128]. Furthermore, these studies demonstrated steady state methanol production rate of $88 \mu \mathrm{mol} \mathrm{g} \mathrm{gat}^{-1}$ for $\mathrm{Cu}-\mathrm{Na}-\mathrm{ZSM}-5$, which is approximately five times higher than that observed by previous researchers in the stepwise and stoichiometric oxidation of methane over similar zeolites [116]. The catalytic turnover of $\mathrm{Cu}-\mathrm{Na}-\mathrm{ZSM}-5$ was confirmed based on results obtained from kinetic and isotopic labeling studies.

Román-Leshkov et al. also studied the catalytic oxidation of methane over other zeolite topologies exchanged with $\mathrm{Cu}$, including H-ferrierite, H-Beta, H-mordenite, Na-Y, and MCM-41 [128]. All of these materials showed catalytic activity toward methanol production, but at lower specific activities compared to $\mathrm{Cu}-\mathrm{H}-\mathrm{ZSM}-5$. Zeolites with CHA topology exhibited the highest site time yields compared to zeolites with MFI topology at similar $\mathrm{Cu} / \mathrm{Al}$ ratio [128]. For methane oxidation reactions conducted at higher temperatures (e.g., $260^{\circ} \mathrm{C}$ ) with $\mathrm{Cu}-\mathrm{Na}-\mathrm{SSZ}-13$ site time yields were shown to increase to $31.6 \times 10^{-3}$ $\operatorname{mol}_{\mathrm{CH} 3 \mathrm{OH}}(\mathrm{mol} \mathrm{Cu})^{-1} \mathrm{~h}^{-1}[128]$. Based on these findings, which indicated that small pore zeolites or cagelike structures have higher performance for methanol production compared to larger pore zeolites, the authors hypothesized that the structure of the catalytic sites or transition states are influenced by the zeolite topology. Although, the catalytic reaction rates for the $\mathrm{Cu}$-exchanged zeolites studied by RománLeshkov et al. are relatively low, the discovery of pretreatment and reaction conditions favoring oxidation of methane is of significant contribution to the development of technologies for the catalytic direct production of methanol from methane [128]. 
The recent advances in the low temperature conversion of methane to methanol discussed in this short review have predominantly focused on the use of transition metal exchanged-zeolites and molecular oxygen. However, pioneering studies on methane oxidation processes using metal organic frameworks [129, 130], covalent triazine frameworks [131, 132], homogeneous metal complexes [133], and various oxidizing agents (e.g., hydrogen peroxide, $\mathrm{N}_{2} \mathrm{O}$, oxygen) have been discussed in more comprehensive reviews [97-99].

\section{Other methane conversion processes}

Electrochemical Oxidation. Electrochemical oxidation of methane has been considered as a direct route for generation of electrical energy from methane. The most commonly used electrochemical systems for direct electrochemical methane oxidation are solid oxide fuel cells (SOFCs). SOFCs are solid-state electrochemical devices that can in principle convert the chemical energy of combustible fuels $\left(\mathrm{H}_{2}, \mathrm{CO}\right.$ and hydrocarbons (such as methane)) directly into electrical energy. The SOFC cathode is responsible for reducing gas-phase oxygen into oxygen ions in the presence of electrons. Oxygen ions are then transported through an ion-conducting oxide (such as yttria stabilized zirconia - YSZ) to the SOFC anode, the electrode where the fuel is fed and oxidized in the presence of the oxygen ions to $\mathrm{CO}_{2}$ and $\mathrm{H}_{2} \mathrm{O}$, releasing electrons to an external circuit. While direct electrochemical oxidation of methane using SOFCs is an appealing approach for the direct generation of electrical energy from methane, there are a number of operational challenges that have been impeding its industrial implementation [25, 134-141]. One challenge is the deactivation of the conventional anode electrocatalyst $(\mathrm{Ni})$ due to carbon poisoning $[25,134,135,139]$. An approach to alleviate this problem is to develop SOFC anode electrocatalysts that are inherently resistant to carbon poisoning $[142,143]$. An attempt toward this direction was made by Gorte and coworkers, who showed that replacing $\mathrm{Ni} / \mathrm{YSZ}$ with $\mathrm{Cu} / \mathrm{CeO}_{2} / \mathrm{YSZ}$ anodes led to improvements in the carbon-tolerance during on-cell, electro-oxidation of methane $[35,37,134,144-$ 146]. Nikolla and co-workers also showed that $\mathrm{Sn} / \mathrm{Ni}$ surface alloy-based SOFC anode electrocatalysts exhibited improved tolerance to carbon-induced deactivation as compared to conventional monometallic 
Ni electrocatalysts [147]. Other attempts in identifying carbon-tolerant anode electrocatalysts for direct electro-oxidation of methane in SOFCs have focused on the use of mixed ionic-electronic conducting oxides as anode electrocatalysts [143, 148-152]. While some mixed ionic-electronic conducting oxides have shown promise, their activity toward methane electro-oxidation is much lower when compared to Ni-based anodes.

Low Temperature Total Oxidation. Low temperature total oxidation or combustion of methane is a process that plays a critical role in automobile emissions. While not directly related to generation of fuels, chemicals and electricity from methane, this process is critical for minimizing methane emissions from automotive exhaust. The commonly used catalysts for this process are Pd-based supported on oxides to facilitate operation at temperatures lower than $400{ }^{\circ} \mathrm{C}$. It has been recently shown that encapsulation of $\mathrm{Pd}$ nanocatalytic particles with reducible oxides, such as ceria, can significantly improve the activity and stability of these catalysts $[153,154]$. The enhancement in the activity was attributed to the structural and chemical features of the ordered Pd-O-Ce moieties [154].

Halogenation and Oxyhalogenation of Methane. Another route for the activation of the $\mathrm{C}-\mathrm{H}$ bond in methane is based on halogenation and oxyhalogenation processes [5, 155-158]. The reaction chemistry for halogenation consists of reacting methane with a halogen (preferably $\mathrm{Cl}_{2}$ or $\mathrm{Br}_{2}$ ) under mild reaction conditions to yield methyl halides $\left(\mathrm{CH}_{3} \mathrm{X}\right)$, which can then undergo catalytic hydrolysis reactions to produce oxygenates, alkanes, olefins, and aromatics. In oxyhalogenation, the $\mathrm{C}-\mathrm{H}$ bond in methane is activated by a reactive halogen that is formed by oxidation of a hydrogen halide with $\mathrm{O}_{2}$. The alkyl halide formed then reacts to produce aromatics or olefins through coupling reactions [158-161]. Olah et al. showed that halogenation of methane to methyl halide over supported acidic catalysts under mild reaction conditions (e.g., $180-250{ }^{\circ} \mathrm{C}$ ) led to selectivities of $>90 \%$ [162]. Although halogenation processes are attractive owing to the relatively low energy barrier for methane $\mathrm{C}-\mathrm{H}$ bond activation via the halogen, drawbacks exist to these processes, such as the regeneration of the halogen to close the catalytic cycle. To overcome such limitation, $\mathrm{Li}$ et al. demonstrated the one-pot catalytic partial oxidation of methane to methanol and dimethyl ether over supported $\mathrm{MoO}_{2} \mathrm{Br}_{2}\left(\mathrm{H}_{2} \mathrm{O}\right)_{2}$ on $\mathrm{Zn}-\mathrm{MCM}-48$ [157]. The process involves 
the formation of $\mathrm{Br}_{2}$ by decomposition of $\mathrm{MoO}_{2} \mathrm{Br}_{2}\left(\mathrm{H}_{2} \mathrm{O}\right)_{2}$ in the presence of $\mathrm{O}_{2}$, followed by the halogenation of methane to form a $\mathrm{CH}_{3} \mathrm{Br}$ species, which is then converted to oxygenated products by reaction with $\mathrm{MoO}_{3}$ in-sync with the regeneration of the $\mathrm{MoO}_{2} \mathrm{Br}_{2}$ species. This process presents a closed catalytic cycle for partial oxidation of methane, however, the efficiency of each step in the process must be optimized to increase product selectivity. Recently, Pérez-Ramírez et al. demonstrated a highly attractive process integrating alkane bromination and oxidation steps [4]. The selective route consisted of the gas-phase bromination of methane coupled with the oxidation of the $\mathrm{HBr}$ by-product to bromine over a vanadium phosphate (VPO) catalyst. The VPO catalyst assisted in providing a continuous source of bromine through the regeneration of $\mathrm{HBr}$ by oxidation over the catalyst surface. In the studies conducted by Pérez-Ramírez et al. selectivities to $\mathrm{CH}_{3} \mathrm{Br}$ of up to $95 \%$ were obtained with stable operation of the catalyst with time on stream [4]. The high selectivity toward $\mathrm{CH}_{3} \mathrm{Br}$ was attributed to the high activity of the catalyst for $\mathrm{HBr}$ oxidation and low activity toward the oxidation of methane and the methyl halide. In more recent work, Pérez-Ramírez et al. demonstrated the one-step production of $\mathrm{CO}$ from methane by selective oxychlorination, yields of up to $35 \%$ at $96 \%$ selectivity of CO were obtained over stable VPO

catalyst at mild reaction conditions [163]. The process involved an approach combining $\mathrm{C}-\mathrm{H}$ bond activation in the presence of $\mathrm{HCl}$ and $\mathrm{O}_{2}$ yielding $\mathrm{CH}_{3} \mathrm{Cl}$ and $\mathrm{CH}_{2} \mathrm{Cl}_{2}$, followed by the in-situ oxidation of halogenated products to $\mathrm{CO}$ and the regeneration of $\mathrm{HCl}$ over the VPO catalyst. This methane conversion strategy presents an alternative to the use of steam-reforming processes for the production of $\mathrm{CO}$ from methane.

\section{Perspective}

The conversion of the simplest but most unreactive hydrocarbon molecule, methane, remains one of the most significant and promising challenges in chemical/electrochemical catalysis research. With the advent of abundant untapped natural gas reserves, the direct transformation of methane as a feedstock for chemicals and fuels has become key in the current society, which is highly dependent on limited resources of crude oil. Despite the number of products (e.g., ethylene, aromatics, methanol, 
formaldehyde, etc.), that could be obtained from the direct conversion of methane, large-scale industrial processing still relies on its conversion to chemicals and fuels through the production of synthesis gas. Hence, development of technologies for the industrial production of chemicals and fuels from direct conversion of methane has not made substantial progress in the recent years. However, progress in fundamental knowledge on catalysts design, synthesis, in-situ and ex-situ characterization, and theoretical work as presented in this short review has shed light into important aspects in the pursuit for active and selective catalytic materials for direct methane conversion processes.

The area of high temperature methane conversion has been mainly dominated by processes that lead to generation of synthesis gas from methane. A promising high temperature route for direct conversion of methane to valuable fuels and chemicals is through oxidative coupling (OCM) and nonoxidative conversion of methane. While promising, OCM with molecular oxygen in packed bed reactors has inherent limitations in the yields of $\mathrm{C}_{2+}$ hydrocarbon products. Whereas, strategies in improving the performance of heterogeneous catalysts and reactor design have been pursued, methane conversions and selectivities toward $\mathrm{C}_{2+}$ products are still far from industrial standards. An approach to improve $\mathrm{C}_{2+}$ product selectivity during OCM is to use membrane reactors. While high $\mathrm{C}_{2+}$ product selectivity has been demonstrated for these systems, methane conversions are low, leading to low overall yields to the desired products. Development of membrane systems with high surface area and improved oxygen conductivity is important toward achieving industrially relevant conversions and yields. Direct electrochemical oxidation of methane to electricity is another approach for efficient conversion of methane. This process has been successfully demonstrated using SOFCs, but long-term stability of these systems has presented challenges. Combined experimental and theoretical approaches have provided the initial important steps toward improving the stability of SOFC electrocatalysts when operating on methane, but further optimization of the electrocatalytic materials is necessary for large-scale implementation.

In low temperature oxidation of methane to methanol a number of active site structures have been suggested including mono metal-oxo species, multinuclear metal-oxo species, large metal-oxide clusters, and metal cations. Scientific findings discussed in this short review have also indicated that zeolite 
topology, Si/Al ratio, and zeolite exchange preparation methods can affect the formation and stabilization of catalytic sites. Hence, future studies aimed at synthesizing metal-exchanged zeolites with well-defined active sites to create a single site type of catalyst will be imperative to establish relationships between reactivity and active site structure. In addition, determining active site stability, formation, and regeneration conditions will be essential for the direct oxidation of methane through a truly catalytic process. Therefore, identifying the nature of the active sites under relevant reaction conditions by in-situ and in-operando spectroscopy studies, combined with kinetic studies and DFT calculations will be essential for the further engineering of materials for the catalytic production of high-value chemicals from methane conversion processes discussed herein.

\section{Acknowledgements}

Wang and Nikolla gratefully acknowledge the support of the National Science Foundation (NSF) (DMREF-1436193). Nikolla also acknowledges the Camille Dreyfus Teacher-Scholar Award from the Camille \& Henry Dreyfus Foundation. Albarracín-Suazo and Pagán-Torres wish to acknowledge support from the Puerto Rico Institute of Functional Materials Program under the NSF Award No. EPS10002410.

\section{References}

[1] R.A. Kerr, Global warming is changing the world, Science, 316 (2007) 188-190.

[2] Q. Wang, X. Chen, A.N. Jha, H. Rogers, Natural gas from shale formation - The evolution, evidences and challenges of shale gas revolution in United States, Renew. Sustainable Energy Rev., 30 (2014) 1-28. [3] R. Horn, R. Schlogl, Methane activation by heterogeneous catalysis, Catal. Lett., 145 (2015) 23-39.

[4] V. Paunovic, G. Zichittella, M. Moser, A.P. Amrute, J. Perez-Ramirez, Catalyst design for natural-gas upgrading through oxybromination chemistry, Nat. Chem., 8 (2016) 803-809.

[5] E. McFarland, Unconventional chemistry for unconventional natural gas, Science, 338 (2012) 340342.

[6] H.S. Bengaard, J.K. Norskov, J. Sehested, B.S. Clausen, L.P. Nielsen, A.M. Molenbroek, J.R. Rostrup-Nielsen, Steam reforming and graphite formation on Ni catalysts, J. Catal., 209 (2002) 365-384. [7] G.E. Keller, M.M. Bhasin, Synthesis of ethylene via oxidative coupling of methane. 1. Determination of active catalysts, J. Catal., 73 (1982) 9-19.

[8] W. Hinsen, M. Baerns, Oxidative coupling of methane to C2-hydrocarbons in the presence of different catalysts, Chem. Ztg., 107 (1983) 223-226.

[9] J.R. Rostrup-Nielsen, Catalytic steam reforming, Catalysis - science and technology, Springer, Berlin, 1984. 
[10] J.R. Rostrupnielsen, J.H.B. Hansen, $\mathrm{CO}_{2}$-reforming of methane over transition-metals, J. Catal., 144 (1993) 38-49.

[11] J.H. Lunsford, The catalytic oxidative coupling of methane, Angew. Chem. Int. Ed., 34 (1995) 970980.

[12] D. Pakhare, J. Spivey, A review of dry $\left(\mathrm{CO}_{2}\right)$ reforming of methane over noble metal catalysts, Chem. Soc. Rev., 43 (2014) 7813-7837.

[13] J.H. Lunsford, Catalytic conversion of methane to more useful chemicals and fuels: a challenge for the 21st century, Catal. Today, 63 (2000) 165-174.

[14] B.C. Enger, R. Lodeng, A. Holmen, A review of catalytic partial oxidation of methane to synthesis gas with emphasis on reaction mechanisms over transition metal catalysts, Appl. Catal., A, 346 (2008) 127.

[15] A.I. Olivos-Suarez, A. Szecsenyi, E.J.M. Hensen, J. Ruiz-Martinez, E.A. Pidko, J. Gascon, Strategies for the direct catalytic valorization of eethane using heterogeneous catalysis: challenges and opportunities, ACS Catal., 6 (2016) 2965-2981.

[16] P. Tang, Q.J. Zhu, Z.X. Wu, D. Ma, Methane activation: the past and future, Energ. Environ. Sci., 7 (2014) 2580-2591.

[17] E. Achenbach, E. Riensche, Methane steam reforming kinetics for solid oxide fuel-cells, J. Power Sources, 52 (1994) 283-288.

[18] F. Abild-Pedersen, O. Lytken, J. Engbaek, G. Nielsen, I. Chorkendorff, J.K. Norskov, Methane activation on Ni(111): effects of poisons and step defects, Surf. Sci., 590 (2005) 127-137.

[19] R.M. Watwe, H.S. Bengaard, J.R. Rostrup-Nielsen, J.A. Dumesic, J.K. Norskov, Theoretical studies of stability and reactivity of CHx species on Ni(111), J. Catal., 189 (2000) 16-30.

[20] J.M. Wei, E. Iglesia, Isotopic and kinetic assessment of the mechanism of reactions of $\mathrm{CH}_{4}$ with $\mathrm{CO}_{2}$ or $\mathrm{H}_{2} \mathrm{O}$ to form synthesis gas and carbon on nickel catalysts, J. Catal., 224 (2004) 370-383.

[21] G. Jones, J.G. Jakobsen, S.S. Shim, J. Kleis, M.P. Andersson, J. Rossmeisl, F. Abild-Pedersen, T. Bligaard, S. Helveg, B. Hinnemann, J.R. Rostrup-Nielsen, I. Chorkendorff, J. Sehested, J.K. Norskov, First principles calculations and experimental insight into methane steam reforming over transition metal catalysts, J. Catal., 259 (2008) 147-160.

[22] J.R. Rostrup-Nielsen, T.S. Christensen, I. Dybkjaer, Steam reforming of liquid hydrocarbons, Stud. Surf. Sci. Catal., 113 (1998) 81-95.

[23] J.R. Rostrupnielsen, L.J. Christiansen, Internal steam reforming in fuel-cells and alkali poisoning, Appl. Catal., A, 126 (1995) 381-390.

[24] N.C. Triantafyllopoulos, S.G. Neophytides, The nature and binding strength of carbon adspecies formed during the equilibrium dissociative adsorption of $\mathrm{CH}_{4}$ on Ni-YSZ cermet catalysts, J. Catal., 217 (2003) 324-333.

[25] T. Takeguchi, Y. Kani, T. Yano, R. Kikuchi, K. Eguchi, K. Tsujimoto, Y. Uchida, A. Ueno, K. Omoshiki, M. Aizawa, Study on steam reforming of $\mathrm{CH}_{4}$ and $\mathrm{C}-2$ hydrocarbons and carbon deposition on Ni-YSZ cermets, J. Power Sources, 112 (2002) 588-595.

[26] J. Rostrup-Nielsen, J.K. Norskov, Step sites in syngas catalysis, Top. Catal., 40 (2006) 45-48.

[27] F. Abild-Pedersen, J.K. Norskov, J.R. Rostrup-Nielsen, J. Sehested, S. Helveg, Mechanisms for catalytic carbon nanofiber growth studied by ab initio density functional theory calculations, Phys. Rev., B, 73 (2006) -.

[28] D. Chen, K.O. Christensen, E. Ochoa-Fernandez, Z.X. Yu, B. Totdal, N. Latorre, A. Monzon, A. Holmen, Synthesis of carbon nanofibers: effects of Ni crystal size during methane decomposition, J. Catal., 229 (2005) 82-96.

[29] S. Helveg, C. Lopez-Cartes, J. Sehested, P.L. Hansen, B.S. Clausen, J.R. Rostrup-Nielsen, F. AbildPedersen, J.K. Norskov, Atomic-scale imaging of carbon nanofibre growth, Nature, 427 (2004) 426-429. [30] D.L. Trimm, Coke formation and minimisation during steam reforming reactions, Catal. Today, 37 (1997) 233-238.

[31] E. Nikolla, J. Schwank, S. Linic, Promotion of the long-term stability of reforming Ni catalysts by surface alloying, J. Catal., 250 (2007) 85-93. 
[32] E. Nikolla, J.W. Schwank, S. Linic, Hydrocarbon steam reforming on Ni alloys at solid oxide fuel cell operating conditions, Catal. Today, 136 (2008) 243-248.

[33] E. Nikolla, J. Schwank, S. Linic, Comparative study of the kinetics of methane steam reforming on supported $\mathrm{Ni}$ and $\mathrm{Sn} / \mathrm{Ni}$ alloy catalysts: The impact of the formation of Ni alloy on chemistry, J. Catal., 263 (2009) 220-227.

[34] E. Nikolla, A. Holewinski, J. Schwank, S. Linic, Controlling carbon surface chemistry by alloying: Carbon tolerant reforming catalyst, J. Am. Chem. Soc., 128 (2006) 11354-11355.

[35] H. Kim, C. Lu, W.L. Worrell, J.M. Vohs, R.J. Gorte, Cu-Ni cermet anodes for direct oxidation of methane in solid-oxide fuel cells, J. Electrochem. Soc., 149 (2002) A247-A250.

[36] D.L. Trimm, Catalysts for the control of coking during steam reforming, Catal. Today, 49 (1999) 310.

[37] R.J. Gorte, J.M. Vohs, Novel SOFC anodes for the direct electrochemical oxidation of hydrocarbons, J. Catal., 216 (2003) 477-486.

[38] V.V. Kharton, F.M. Figueiredo, L. Navarro, E.N. Naumovich, A.V. Kovalevsky, A.A.

Yaremchenko, A.P. Viskup, A. Carneiro, F.M.B. Marques, J.R. Frade, Ceria-based materials for solid oxide fuel cells, J. Mater. Sci., 36 (2001) 1105-1117.

[39] Z.Y. Hou, O. Yokota, T. Tanaka, T. Yashima, Surface properties of a coke-free Sn doped nickel catalyst for the $\mathrm{CO}_{2}$ reforming of methane, Appl. Surf. Sci., 233 (2004) 58-68.

[40] N. Nichio, M.L. Casella, G.F. Santori, E.N. Ponzi, O.A. Ferretti, Stability promotion of Ni/alpha$\mathrm{Al}_{2} \mathrm{O}_{3}$ catalysts by tin added via surface organometallic chemistry on metals - Application in methane reforming processes, Catal. Today, 62 (2000) 231-240.

[41] J.W. Shabaker, G.W. Huber, J.A. Dumesic, Aqueous-phase reforming of oxygenated hydrocarbons over Sn-modified Ni catalysts, J. Catal., 222 (2004) 180-191.

[42] J. Xu, M. Saeys, Improving the coking resistance of Ni-based catalysts by promotion with subsurface boron, J. Catal., 242 (2006) 217-226.

[43] F. Besenbacher, I. Chorkendorff, B.S. Clausen, B. Hammer, A.M. Molenbroek, J.K. Norskov, I. Stensgaard, Design of a surface alloy catalyst for steam reforming, Science, 279 (1998) 1913-1915.

[44] E. Nikolla, J. Schwank, S. Linic, Measuring and relating the electronic structures of nonmodel supported catalytic materials to their performance, J. Am. Chem. Soc., 131 (2009) 2747-2754.

[45] Rostrupn.Jr, Activity of nickel catalysts for steam reforming of hydrocarbons, J. Catal., 31 (1973) 173-199.

[46] J.M. Wei, E. Iglesia, Mechanism and site requirements for activation and chemical conversion of methane on supported Pt clusters and turnover rate comparisons among noble metals, J. Phys. Chem., B, 108 (2004) 4094-4103.

[47] J.M. Wei, E. Iglesia, Reaction pathways and site requirements for the activation and chemical conversion of methane on Ru-based catalysts, J. Phys. Chem., B, 108 (2004) 7253-7262.

[48] E. Kikuchi, S. Tanaka, Y. Yamazaki, Y. Morita, Steam reforming of hydrocarbons on noble metal catalysts (Part 1) The catalytic activity in methane-steam reaction, Bull. Jpn. Pet. Inst., 16 (1974) 4. [49] J.M. Wei, E. Iglesia, Structural requirements and reaction pathways in methane activation and chemical conversion catalyzed by rhodium, J. Catal., 225 (2004) 116-127.

[50] S.G. Wang, X.Y. Liao, J. Hu, D.B. Cao, Y.W. Li, J.G. Wang, H.J. Jiao, Kinetic aspect of $\mathrm{CO}_{2}$ reforming of $\mathrm{CH}_{4}$ on $\mathrm{Ni}(111)$ : a density functional theory calculation, Surf. Sci., 601 (2007) 1271-1284.

[51] E.X. Verykios, Mechanistic aspects of the reaction of $\mathrm{CO}_{2}$ reforming of methane over $\mathrm{Rh} / \mathrm{Al}_{2} \mathrm{O}_{3}$ catalyst, Appl. Catal., A, 255 (2003) 101-111.

[52] P. Gronchi, P. Centola, R. Del Rosso, Dry reforming of $\mathrm{CH}_{4}$ with $\mathrm{Ni}$ and $\mathrm{Rh}$ metal catalysts supported on $\mathrm{SiO}_{2}$ and $\mathrm{La}_{2} \mathrm{O}_{3}$, Appl. Catal., A, 152 (1997) 83-92.

[53] P. Djinovic, J. Batista, A. Pintar, Efficient catalytic abatement of greenhouse gases: Methane reforming with $\mathrm{CO}_{2}$ using a novel and thermally stable $\mathrm{Rh}-\mathrm{CeO}_{2}$ catalyst, Int. J. Hydrogen Energ., 37 (2012) 2699-2707.

[54] G. Kumar, S.L.J. Lau, M.D. Krcha, M.J. Janik, Correlation of methane activation and oxide catalyst reducibility and its implications for oxidative coupling, ACS Catal., 6 (2016) 1812-1821. 
[55] T. Ito, J.X. Wang, C.H. Lin, J.H. Lunsford, Oxidative dimerization of methane over a lithiumpromoted magnesium-oxide catalyst, J. Am. Chem. Soc., 107 (1985) 5062-5068.

[56] C.H. Lin, T. Ito, J.X. Wang, J.H. Lunsford, Oxidative dimerization of methane over magnesium and calcium-oxide catalysts promoted with group IA ions - the role of $\left[\mathrm{M}^{+} \mathrm{O}^{-}\right]$centers, J. Am. Chem. Soc., 109 (1987) 4808-4810.

[57] B.L. Farrell, S. Linic, Oxidative coupling of methane over mixed oxide catalysts designed for solid oxide membrane reactors, Catal. Sci. Technol., 6 (2016) 4370-4376.

[58] Y. Zeng, Y.S. Lin, S.L. Swartz, Perovskite-type ceramic membrane: synthesis, oxygen permeation and membrane reactor performance for oxidative coupling of methane, J. Membrane Sci., 150 (1998) 8798.

[59] Y. Zeng, Y.S. Lin, Oxygen permeation and oxidative coupling of methane in yttria doped bismuth oxide membrane reactor, J. Catal., 193 (2000) 58-64.

[60] Y. Zeng, F.T. Akin, Y.S. Lin, Oxidative coupling of methane on fluorite-structured samariumyttrium-bismuth oxide, Appl. Catal., A, 213 (2001) 33-45.

[61] J.J. Wu, H.L. Zhang, S. Qin, C.W. Hu, La-promoted $\mathrm{Na}_{2} \mathrm{WO}_{4} / \mathrm{Mn} / \mathrm{SiO}_{2}$ catalysts for the oxidative conversion of methane simultaneously to ethylene and carbon monoxide, Appl. Catal., A, 323 (2007) 126-134.

[62] H.H. Wang, Y. Cong, W.S. Yang, Oxidative coupling of methane in $\mathrm{Ba}_{0.5} \mathrm{Sr}_{0.5} \mathrm{Co}_{0.8} \mathrm{Fe}_{0.2} \mathrm{O}_{3-\mathrm{d}}$ tubular membrane reactors, Catal. Today, 104 (2005) 160-167.

[63] D.J. Wang, M.P. Rosynek, J.H. Lunsford, Oxidative coupling of methane over oxide-supported sodium-manganese catalysts, J. Catal., 155 (1995) 390-402.

[64] X.Y. Tan, K. Li, Oxidative coupling of methane in a perovskite hollow-fiber membrane reactor, Ind.

Eng. Chem. Res., 45 (2006) 142-149.

[65] S. Pak, P. Qiu, J.H. Lunsford, Elementary reactions in the oxidative coupling of methane over $\mathrm{Mn} / \mathrm{Na}_{2} \mathrm{WO}_{4} / \mathrm{SiO}_{2}$ and $\mathrm{Mn} / \mathrm{Na}_{2} \mathrm{WO}_{4} / \mathrm{MgO}$ catalysts, J. Catal., 179 (1998) 222-230.

[66] K. Otsuka, Q. Liu, A. Morikawa, Selective synthesis of ethylene by partial oxidation of methane over LiCl-Sm ${ }_{2} \mathrm{O}_{3}$, J. Chem. Soc. Chem. Comm., (1986) 586-587.

[67] K. Otsuka, T. Komatsu, Active catalysts in oxidative coupling of methane, J. Chem. Soc. Chem. Comm., (1987) 388-389.

[68] L. Olivier, S. Haag, C. Mirodatos, A.C. van Veen, Oxidative coupling of methane using catalyst modified dense perovskite membrane reactors, Catal. Today, 142 (2009) 34-41.

[69] K. Murata, T. Hayakawa, K.I. Fujita, Excellent effect of lithium-doped sulfated zirconia catalysts for oxidative coupling of methane to give ethene and ethane, Chem. Commun., (1997) 221-222.

[70] Y.P. Lu, A.G. Dixon, W.R. Moser, Y.H. Ma, U. Balachandran, Oxidative coupling of methane using oxygen-permeable dense membrane reactors, Catal. Today, 56 (2000) 297-305.

[71] Y.P. Lu, A.G. Dixon, W.R. Moser, Y.H. Ma, Oxidative coupling of methane in a modified gammaalumina membrane reactor, Chem. Eng. Sci., 55 (2000) 4901-4912.

[72] H. Imai, T. Tagawa, Oxidative coupling of methane over $\mathrm{LaAlO}_{3}$, J. Chem. Soc. Chem. Comm., (1986) 52-53.

[73] G.J. Hutchings, M.S. Scurrell, J.R. Woodhouse, Oxidative coupling of methane using oxide catalysts, Chem. Soc. Rev., 18 (1989) 251-283.

[74] J.M. Deboy, R.F. Hicks, The oxidative coupling of methane over alkali, alkaline-earth, and rare-earth oxides, Ind. Eng. Chem. Res., 27 (1988) 1577-1582.

[75] O. Czuprat, T. Schiestel, H. Voss, J. Caro, Oxidative coupling of methane in a BCFZ perovskite hollow fiber membrane reactor, Ind. Eng. Chem. Res., 49 (2010) 10230-10236.

[76] J. Coronas, M. Menendez, J. Santamaria, Methane oxidative coupling using porous ceramic membrane reactors. 2. Reaction studies, Chem. Eng. Sci., 49 (1994) 2015-2025.

[77] J.A. Labinger, Oxidative coupling of methane: An inherent limit to selectivity?, Catal. Lett., 1 (1988) 371-375.

[78] B.L. Farrell, V.O. Igenegbai, S. Linic, A viewpoint on direct methane conversion to ethane and ethylene using oxidative coupling on solid catalysts, ACS Catal., 6 (2016) 4340-4346. 
[79] K. Kwapien, J. Paier, J. Sauer, M. Geske, U. Zavyalova, R. Horn, P. Schwach, A. Trunschke, R. Schlogl, Sites for methane activation on lithium-doped magnesium oxide surfaces, Angew. Chem. Int. Ed., 53 (2014) 8774-8778.

[80] U. Zavyalova, M. Holena, R. Schlogl, M. Baerns, Statistical analysis of past catalytic data on oxidative methane coupling for new insights into the composition of high-performance catalysts, Chemcatchem, 3 (2011) 1935-1947.

[81] Q.J. Zhu, S.L. Wegener, C. Xie, O. Uche, M. Neurock, T.J. Marks, Sulfur as a selective 'soft' oxidant for catalytic methane conversion probed by experiment and theory, Nat. Chem., 5 (2013) 104-109.

[82] D. Eng, M. Stoukides, Catalytic and electrocatalytic methane oxidation with solid oxide membranes, Catal. Rev., 33 (1991) 375-412.

[83] P.H. Chiang, D. Eng, H. Alqahtany, M. Stoukides, Nonoxidative methane coupling with the aid of solid electrolytes, Solid State Ionics, 53 (1992) 135-141.

[84] A. Das, E. Xhafa, E. Nikolla, Electro- and thermal-catalysis by layered, first series RuddlesdenPopper oxides, Catal. Today, (2016).

[85] X.G. Guo, G.Z. Fang, G. Li, H. Ma, H.J. Fan, L. Yu, C. Ma, X. Wu, D.H. Deng, M.M. Wei, D.L.

Tan, R. Si, S. Zhang, J.Q. Li, L.T. Sun, Z.C. Tang, X.L. Pan, X.H. Bao, Direct, nonoxidative conversion of methane to ethylene, aromatics, and hydrogen, Science, 344 (2014) 616-619.

[86] S.T. Liu, Q. Dong, R. Ohnishi, M. Ichikawa, Remarkable non-oxidative conversion of methane to naphthalene and benzene on Co and Fe modified Mo/HZSM-5 catalysts, Chem. Commun., (1997) 14551456.

[87] S.B. Derouane-Abd Hamid, J.R. Anderson, I. Schmidt, C. Bouchy, C.J.H. Jacobsen, E.G. Derouane, Effect of the activation procedure on the performance of Mo/H-MFI catalysts for the non-oxidative conversion of methane to aromatics, Catal. Today, 63 (2000) 461-469.

[88] G.A. Olah, Beyond oil and gas: the methanol economy, Angew. Chem. Int. Ed., 44 (2005) 26362639.

[89] G.A. Olah, A. Goeppert, G.K.S. Prakash, Methanol and dimethyl ether as fuels and energy carriers, Beyond oil and gas: The methanol economy, Wiley-VCH Verlag GmbH \& Co. KGaA2009, pp. 185-231. [90] G.A. Olah, A. Goeppert, G.K.S. Prakash, Production of methanol: from fossil fuels and bio-sources to chemical carbon dioxide recycling, Beyond oil and gas: The methanol economy, Wiley-VCH Verlag GmbH \& Co. KGaA2009, pp. 233-278.

[91] J.B. Hansen, P.E. Højlund Nielsen, Methanol synthesis, Handbook of heterogeneous catalysis, Wiley-VCH Verlag GmbH \& Co. KGaA2008.

[92] V. Arutyunov, Low-scale direct methane to methanol - Modern status and future prospects, Catal. Today, 215 (2013) 243-250.

[93] R. Balasubramanian, S.M. Smith, S. Rawat, L.A. Yatsunyk, T.L. Stemmler, A.C. Rosenzweig, Oxidation of methane by a biological dicopper centre, Nature, 465 (2010) 115-119.

[94] A.C. Rosenzweig, C.A. Frederick, S.J. Lippard, P. Nordlund, Crystal structure of a bacterial nonhaem iron hydroxylase that catalyses the biological oxidation of methane, Nature, 366 (1993) 537-543.

[95] R.L. Lieberman, A.C. Rosenzweig, Crystal structure of a membrane-bound metalloenzyme that catalyses the biological oxidation of methane, Nature, 434 (2005) 177-182.

[96] A.S. Hakemian, A.C. Rosenzweig, The biochemistry of methane oxidation, Annu. Rev. Biochem., 76 (2007) 223-241.

[97] C. Hammond, S. Conrad, I. Hermans, Oxidative methane upgrading, ChemSusChem, 5 (2012) 16681686.

[98] A.I. Olivos-Suarez, À. Szécsényi, E.J.M. Hensen, J. Ruiz-Martinez, E.A. Pidko, J. Gascon, Strategies for the direct catalytic valorization of methane using heterogeneous catalysis: challenges and opportunities, ACS Catal., 6 (2016) 2965-2981.

[99] Z. Guo, B. Liu, Q. Zhang, W. Deng, Y. Wang, Y. Yang, Recent advances in heterogeneous selective oxidation catalysis for sustainable chemistry, Chem. Soc. Rev., 43 (2014) 3480-3524.

[100] R.A. Himes, K. Barnese, K.D. Karlin, One is lonely and three is a crowd: Two coppers are for methane oxidation, Angew. Chem. Int. Ed., 49 (2010) 6714-6716. 
[101] G.I. Pannov, V.I. Sobolev, A.S. Kharitonov, The role of iron in $\mathrm{N}_{2} \mathrm{O}$ decomposition on ZSM-5 zeolite and reactivity of the surface oxygen formed, J. Mol. Catal., 61 (1990) 85-97.

[102] V.I. Sobolev, K.A. Dubkov, O.V. Panna, G.I. Panov, Proceedings of the second workshop on C1C3 hydrocarbon conversion selective oxidation of methane to methanol on a Fe-ZSM-5 surface, Catal. Today, 24 (1995) 251-252.

[103] K.A. Dubkov, N.S. Ovanesyan, A.A. Shteinman, E.V. Starokon, G.I. Panov, Evolution of iron states and formation of $\alpha$-sites upon activation of Fe-ZSM-5 zeolites, J. Catal., 207 (2002) 341-352.

[104] M.H. Groothaert, P.J. Smeets, B.F. Sels, P.A. Jacobs, R.A. Schoonheydt, Selective oxidation of methane by the bis( $\mu$-oxo)dicopper core stabilized on ZSM-5 and mordenite zeolites, J. Am. Chem. Soc., 127 (2005) 1394-1395.

[105] M.H. Groothaert, K. Lievens, J.A. van Bokhoven, A.A. Battiston, B.M. Weckhuysen, K. Pierloot, R.A. Schoonheydt, Bis( $\mu$-oxo)dicopper as key intermediate in the catalytic decomposition of nitric oxide, ChemPhysChem, 4 (2003) 626-630.

[106] P.J. Smeets, M.H. Groothaert, R.M. van Teeffelen, H. Leeman, E.J.M. Hensen, R.A. Schoonheydt, Direct $\mathrm{NO}$ and $\mathrm{N}_{2} \mathrm{O}$ decomposition and $\mathrm{NO}$-assisted $\mathrm{N}_{2} \mathrm{O}$ decomposition over Cu-zeolites: Elucidating the influence of the $\mathrm{Cu}-\mathrm{Cu}$ distance on oxygen migration, J. Catal., 245 (2007) 358-368.

[107] M.H. Groothaert, J.A. van Bokhoven, A.A. Battiston, B.M. Weckhuysen, R.A. Schoonheydt, Bis( $\mu-$ oxo)dicopper in Cu-ZSM-5 and its role in the decomposition of NO: A combined in Situ XAFS, UV-Vis-Near-IR, and kinetic study, J. Am. Chem. Soc., 125 (2003) 7629-7640.

[108] J.S. Woertink, P.J. Smeets, M.H. Groothaert, M.A. Vance, B.F. Sels, R.A. Schoonheydt, E.I. Solomon, $\mathrm{A}\left[\mathrm{Cu}_{2} \mathrm{O}\right]^{2+}$ core in $\mathrm{Cu}-\mathrm{ZSM}-5$, the active site in the oxidation of methane to methanol, Proc. Nat. Acad. Sci., 106 (2009) 18908-18913.

[109] P.J. Smeets, R.G. Hadt, J.S. Woertink, P. Vanelderen, R.A. Schoonheydt, B.F. Sels, E.I. Solomon, Oxygen precursor to the reactive intermediate in methanol synthesis by Cu-ZSM-5, J. Am. Chem. Soc., 132 (2010) 14736-14738.

[110] G. Li, P. Vassilev, M. Sanchez-Sanchez, J.A. Lercher, E.J.M. Hensen, E.A. Pidko, Stability and reactivity of copper oxo-clusters in ZSM-5 zeolite for selective methane oxidation to methanol, J. Catal., 338 (2016) 305-312.

[111] M.A.C. Markovits, A. Jentys, M. Tromp, M. Sanchez-Sanchez, J.A. Lercher, Effect of location and distribution of $\mathrm{Al}$ sites in $\mathrm{ZSM}-5$ on the formation of $\mathrm{Cu}-\mathrm{Oxo}$ clusters active for direct conversion of methane to methanol, Top. Catal., (2016) 1-10.

[112] S. Grundner, M.A.C. Markovits, G. Li, M. Tromp, E.A. Pidko, E.J.M. Hensen, A. Jentys, M. Sanchez-Sanchez, J.A. Lercher, Single-site trinuclear copper oxygen clusters in mordenite for selective conversion of methane to methanol, Nat. Commun., 6 (2015).

[113] P. Vanelderen, B.E.R. Snyder, M. Tsai, R.G. Hadt, J. Vancauwenbergh, O. Coussens, R.A. Schoonheydt, B.F. Sels, E.I. Solomon, Spectroscopic definition of the copper active sites in mordenite: selective methane oxidation, J. Am. Chem. Soc., 137 (2015) 6383-6392.

[114] Z. Zhao, A. Kulkarni, L. Vilella, J.K. Nørskov, F. Studt, Theoretical insights into the selective oxidation of methane to methanol in copper-exchanged mordenite, ACS Catal., 6 (2016) 3760-3766. [115] S. Grundner, W. Luo, M. Sanchez-Sanchez, J.A. Lercher, Synthesis of single-site copper catalysts for methane partial oxidation, Chem. Commun., 52 (2016) 2553-2556.

[116] M.J. Wulfers, S. Teketel, B. Ipek, R.F. Lobo, Conversion of methane to methanol on coppercontaining small-pore zeolites and zeotypes, Chem. Commun., 51 (2015) 4447-4450.

[117] A.R. Kulkarni, Z. Zhao, S. Siahrostami, J.K. Nørskov, F. Studt, Monocopper active site for partial methane oxidation in Cu-exchanged 8MR zeolites, ACS Catal., (2016) 6531-6536.

[118] J. Shan, W. Huang, L. Nguyen, Y. Yu, S. Zhang, Y. Li, A.I. Frenkel, F. Tao, Conversion of methane to methanol with a bent mono( $\mu$-oxo)dinickel anchored on the internal surfaces of micropores, Langmuir, 30 (2014) 8558-8569.

[119] N.V. Beznis, B.M. Weckhuysen, J.H. Bitter, Partial oxidation of methane over Co-ZSM-5: Tuning the oxygenate selectivity by altering the preparation route, Catal. Lett., 136 (2010) 52-56. 
[120] N.V. Beznis, A.N.C. van Laak, B.M. Weckhuysen, J.H. Bitter, Oxidation of methane to methanol and formaldehyde over Co-ZSM-5 molecular sieves: Tuning the reactivity and selectivity by alkaline and acid treatments of the zeolite ZSM-5 agglomerates, Microporous and Mesoporous Mater., 138 (2011) 176-183.

[121] J. Xu, A. Zheng, X. Wang, G. Qi, J. Su, J. Du, Z. Gan, J. Wu, W. Wang, F. Deng, Room temperature activation of methane over Zn modified H-ZSM-5 zeolites: Insight from solid-state NMR and theoretical calculations, Chem. Sci., 3 (2012) 2932-2940.

[122] A. Oda, H. Torigoe, A. Itadani, T. Ohkubo, T. Yumura, H. Kobayashi, Y. Kuroda, Mechanism of $\mathrm{CH}_{4}$ activation on a monomeric $\mathrm{Zn}^{2+}$-ion exchanged in MFI-type zeolite with a specific $\mathrm{Al}$ arrangement: similarity to the activation site for $\mathrm{H}_{2}$, J. Phys. Chem., C, 117 (2013) 19525-19534.

[123] H. Schwarz, Chemistry with methane: concepts rather than recipes, Angew. Chem. Int. Ed., 50 (2011) 10096-10115.

[124] M.J. da Silva, Synthesis of methanol from methane: Challenges and advances on the multi-step (syngas) and one-step routes (DMTM), Fuel Process. Technol., 145 (2016) 42-61.

[125] Z. Zakaria, S.K. Kamarudin, Direct conversion technologies of methane to methanol: An overview, Renew. Sustainable Energy Rev., 65 (2016) 250-261.

[126] E.M.C. Alayon, M. Nachtegaal, E. Kleymenov, J.A. van Bokhoven, Determination of the electronic and geometric structure of $\mathrm{Cu}$ sites during methane conversion over $\mathrm{Cu}-\mathrm{MOR}$ with $\mathrm{X}$-ray absorption spectroscopy, Microporous Mesoporous Mater., 166 (2013) 131-136.

[127] S.E. Bozbag, E.M.C. Alayon, J. Pechacek, M. Nachtegaal, M. Ranocchiari, J.A. van Bokhoven, Methane to methanol over copper mordenite: yield improvement through multiple cycles and different synthesis techniques, Catal. Sci. Technol., 6 (2016) 5011-5022.

[128] K. Narsimhan, K. Iyoki, K. Dinh, Y. Román-Leshkov, Catalytic oxidation of methane into methanol over copper-exchanged zeolites with oxygen at low temperature, ACS Cent. Sci., 2 (2016) 424429.

[129] P. Verma, K.D. Vogiatzis, N. Planas, J. Borycz, D.J. Xiao, J.R. Long, L. Gagliardi, D.G. Truhlar, Mechanism of oxidation of ethane to ethanol at iron(IV)-oxo Sites in magnesium-diluted $\mathrm{Fe}_{2}(\mathrm{dobdc})$, J. Am. Chem. Soc., 137 (2015) 5770-5781.

[130] A. Dhakshinamoorthy, A.M. Asiri, H. Garcia, Metal-organic frameworks as catalysts for oxidation reactions, Chem. Eur. J., 22 (2016) 8012-8024.

[131] R. Palkovits, M. Antonietti, P. Kuhn, A. Thomas, F. Schüth, Solid catalysts for the selective lowtemperature oxidation of methane to methanol, Angew. Chem. Int. Ed., 48 (2009) 6909-6912.

[132] R. Palkovits, C. von Malotki, M. Baumgarten, K. Müllen, C. Baltes, M. Antonietti, P. Kuhn, J. Weber, A. Thomas, F. Schüth, Development of molecular and solid catalysts for the direct lowtemperature oxidation of methane to methanol, ChemSusChem, 3 (2010) 277-282.

[133] O.A. Mironov, S.M. Bischof, M.M. Konnick, B.G. Hashiguchi, V.R. Ziatdinov, W.A. Goddard, M. Ahlquist, R.A. Periana, Using reduced catalysts for oxidation reactions: mechanistic studies of the "Periana-Catalytica" system for $\mathrm{CH}_{4}$ oxidation, J. Am. Chem. Soc., 135 (2013) 14644-14658.

[134] A. Atkinson, S. Barnett, R.J. Gorte, J.T.S. Irvine, A.J. Mcevoy, M. Mogensen, S.C. Singhal, J. Vohs, Advanced anodes for high-temperature fuel cells, Nat. Mater., 3 (2004) 17-27.

[135] C.M. Finnerty, N.J. Coe, R.H. Cunningham, R.M. Ormerod, Carbon formation on and deactivation of nickel-based/zirconia anodes in solid oxide fuel cells running on methane, Catal. Today, 46 (1998)

137-145.

[136] H. Yokokawa, H.Y. Tu, B. Iwanschitz, A. Mai, Fundamental mechanisms limiting solid oxide fuel cell durability, J. Power Sources, 182 (2008) 400-412.

[137] E.P. Murray, S.J. Harris, J. Liu, S.A. Barnett, Direct solid oxide fuel cell operation using isooctane, Electrochem. Solid St., 9 (2006) A292-A294.

[138] A. Lashtabeg, S.J. Skinner, Solid oxide fuel cells - a challenge for materials chemists?, J. Mater.

Chem., 16 (2006) 3161-3170.

[139] M. Mogensen, K. Kammer, Conversion of hydrocarbons in solid oxide fuel cells, Annu. Rev.

Mater. Res., 33 (2003) 321-331. 
[140] M.J. Jorgensen, P. Holtappels, C.C. Appel, Durability test of SOFC cathodes, J. Appl. Electrochem., 30 (2000) 411-418.

[141] T.M. Gur, Comprehensive review of methane conversion in solid oxide fuel cells: Prospects for efficient electricity generation from natural gas, Prog. Energ. Combust., 54 (2016) 1-64.

[142] S.W. Zha, A. Moore, H. Abernathy, M.L. Liu, GDC-based low-temperature SOFCs powered by hydrocarbon fuels, J. Electrochem. Soc., 151 (2004) A1128-A1133.

[143] M.R. Pillai, I. Kim, D.M. Bierschenk, S.A. Barnett, Fuel-flexible operation of a solid oxide fuel cell with $\mathrm{Sr}_{0.8} \mathrm{La}_{0.2} \mathrm{TiO}_{3}$ support, J. Power Sources, 185 (2008) 1086-1093.

[144] S.I. Lee, J.M. Vohs, R.J. Gorte, A study of SOFC anodes based on $\mathrm{Cu}-\mathrm{Ni}$ and $\mathrm{Cu}-\mathrm{Co}$ bimetallics in $\mathrm{CeO}_{2}$-YSZ, J. Electrochem. Soc., 151 (2004) A1319-A1323.

[145] S. McIntosh, J.M. Vohs, R.J. Gorte, Impedance spectroscopy for the characterization of Cu-CeriaYSZ anodes for SOFCs, J. Electrochem. Soc., 150 (2003) A1305-A1312.

[146] S. McIntosh, S.B. Adler, J.M. Vohs, R.J. Gorte, Effect of polarization on and implications for characterization of LSM-YSZ composite cathodes, Electrochem. Solid St., 7 (2004) A111-A114.

[147] E. Nikolla, J. Schwank, S. Linic, Direct electrochemical oxidation of hydrocarbon fuels on SOFCs: improved carbon tolerance of Ni alloy anodes, J. Electrochem. Soc., 156 (2009) B1312-B1316.

[148] M.R. Pillai, Y. Jiang, N. Mansourian, I. Kim, D.M. Bierschenk, H.Y. Zhu, R.J. Kee, S.A. Barnett, Solid oxide fuel cell with oxide anode-side support, Electrochem. Solid St., 11 (2008) B174-B177.

[149] G. Kim, M.D. Gross, W. Wang, J.M. Vohs, R.J. Gorte, SOFC anodes based on LST-YSZ composites and on $\mathrm{Y}_{0.04} \mathrm{Ce}_{0.48} \mathrm{Zr}_{0.48} \mathrm{O}_{2}$, J. Electrochem. Soc., 155 (2008) B360-B366.

[150] M.D. Gross, J.M. Vohs, R.J. Gorte, An examination of SOFC anode functional layers based on ceria in YSZ, J. Electrochem. Soc., 154 (2007) B694-B699.

[151] M.D. Gross, J.M. Vohs, R.J. Gorte, Recent progress in SOFC anodes for direct utilization of hydrocarbons, J. Mater. Chem., 17 (2007) 3071-3077.

[152] G. Kim, G. Corre, J.T.S. Irvine, J.M. Vohs, R.J. Gorte, Engineering composite oxide SOFC anodes for efficient oxidation of methane, Electrochem. Solid St., 11 (2008) B16-B19.

[153] M. Cargnello, J.J.D. Jaen, J.C.H. Garrido, K. Bakhmutsky, T. Montini, J.J.C. Gamez, R.J. Gorte, P. Fornasiero, Exceptional activity for methane combustion over modular $\mathrm{Pd} @ \mathrm{CeO}_{2}$ subunits on functionalized $\mathrm{Al}_{2} \mathrm{O}_{3}$, Science, 337 (2012) 713-717.

[154] S. Colussi, A. Gayen, M.F. Camellone, M. Boaro, J. Llorca, S. Fabris, A. Trovarelli, Nanofaceted Pd-O sites in Pd-Ce surface superstructures: enhanced activity in catalytic combustion of methane, Angew. Chem. Int. Ed., 48 (2009) 8481-8484.

[155] E. Peringer, M. Salzinger, M. Hutt, A.A. Lemonidou, J.A. Lercher, Modified lanthanum catalysts for oxidative chlorination of methane, Top. Catal., 52 (2009) 1220-1231.

[156] J.L. He, T. Xu, Z.H. Wang, Q.H. Zhang, W.P. Deng, Y. Wang, Transformation of methane to propylene: A two-step reaction route catalyzed by modified $\mathrm{CeO}_{2}$ nanocrystals and zeolites, Angew. Chem. Int. Ed., 51 (2012) 2438-2442.

[157] F.B. Li, G.Q. Yuan, Hydrated dibromodioxomolybdenum(VI) supported on Zn-MCM-48 for facile oxidation of methane, Angew. Chem. Int. Ed., 45 (2006) 6541-6544.

[158] S.G. Podkolzin, E.E. Stangland, M.E. Jones, E. Peringer, J.A. Lercher, Methyl chloride production from methane over lanthanum-based catalysts, J. Am. Chem. Soc., 129 (2007) 2569-2576.

[159] K.L. Ding, A.R. Derk, A.H. Zhang, Z.P. Hu, P. Stoimenov, G.D. Stucky, H. Metiu, E.W.

McFarland, Hydrodebromination and oligomerization of dibromomethane, ACS Catal., 2 (2012) 479-486. [160] P. Lersch, F. Bandermann, Conversion of Chloromethane over Metal-Exchanged Zsm-5 to Higher Hydrocarbons, Applied Catalysis, 75 (1991) 133-152.

[161] A.H. Zhang, S.L. Sun, Z.J.A. Komon, N. Osterwalder, S. Gadewar, P. Stoimenov, D.J. Auerbach, G.D. Stucky, E.W. McFarland, Improved light olefin yield from methyl bromide coupling over modified SAPO-34 molecular sieves, Phys. Chem. Chem. Phys., 13 (2011) 2550-2555.

[162] G.A. Olah, B. Gupta, M. Farina, J.D. Felberg, W.M. Ip, A. Husain, R. Karpeles, K. Lammertsma, A.K. Melhotra, N.J. Trivedi, Electrophilic reactions at single bonds. 20. Selective monohalogenation of methane over supported acid or platinum metal-catalysts and hydrolysis of methyl halides over gamma- 
alumina-supported metal-oxide hydroxide catalysts - a feasible path for the oxidative conversion of methane into methyl-alcohol dimethyl ether, J. Am. Chem. Soc., 107 (1985) 7097-7105.

[163] V. Paunovic, G. Zichittella, R. Verel, A.P. Amrute, J. Perez-Ramirez, Selective production of carbon monoxide via methane oxychlorination over vanadyl pyrophosphate, Angew. Chem. Int. Ed., 55 (2016) 5 . 